\title{
TÜRK HUKUKUNDA VE KARŞILAȘTIRMALI HUKUKTA GÜMRÜKSÜZ SATIŞ MAĞAZALARI
}

\author{
(Araşsturma Makalesi)
}

DOI: https://doi.org/10.33717/deuhfd.1002848

\section{Dr. Öğr. Üyesi Altan Fahri G̈̈LERCÏ}

\begin{abstract}
$\ddot{O} \mathbf{z}$
“Gümrüksüz satış mağazası” terimi, dünyada yaygın bir uygulaması bulunan "duty-free shop" ifadesinin Türkçe'ye uyarlanmış halidir. Kavramın yaygın ve bilinen adl "duty-free shop" şeklindedir. Bu mağazalar gümrük giriş ve çıkışlarında bulunan ve ancak belirli şartlarl yerine getirenlerin alışveriş yapabildikleri kendine özgü statüsü olan yerlerdir. Bu mağazalar ayrıca gümrük hukukunun kamu karakterinin özel hukuk uygulamasına yansımış bir örneğini teşkil etmektedir. Zira kamu hukuku bu mağazaların sadece kurulması, faaliyete geçmesi, denetimi noktalarında değil, bu măgazalar tarafindan yapılan birtakım özel hukuk işlemlerinde de etkisini göstermektedir. Ancak kamu hukukunun ne kadar etkisi olursa olsun, gümrüksüz satış mağazalarının fiil ve işlemlerinin doğrudan ticaret hukukunu ilgilendirdiği de bir gerçektir. Bu makalede gümrüksüz satış mağazalarının açılması, faaliyetleri, denetimi ve hukuki niteliği konuları ile mağazaların faaliyetlerinin ticaret hukuku boyutuna ilişkin önemli noktalara değinilmiştir. Bu bağlamda gümrüksüz satı̧̧ mağazalarının şube niteliği taşıyıp taşımadıklarl, devri, tekel hakkl, mağazadaki malların haczi ve rehni konularında değerlendirmelerde bulunulmuştur. Ayrıca uygulamada çıkabilecek olası sorunlara da çözüm önerileri sunulmuştur. Makalede konuyla ilgili karşılaştırmalı hukuk incelemesine de yer verilmiştir. Bu kapsamda seçilmiş bazı ülkelerin mevzuatlarındaki durum ayrıntıl olarak ele alınmıştır.
\end{abstract}

\section{Anahtar Kelimeler}

Gümrüksüz satıs, Gümrüksüz satış mağazası, Antrepo, Ticari işletme, Şube

Afyon Kocatepe Üniversitesi Hukuk Fakültesi, Ticaret Hukuku Anabilim Dalı Öğretim Üyesi, Afyonkarahisar (altanfahrigulerci@gmail.com), ORCID: 0000-0001-8731-4181 (Geliş Tarihi: 05.07.2021-Kabul Tarihi: 28.09.2021)

Dokuz Eylül Üniversitesi Hukuk Fakültesi Dergisi, Cilt: 23, Sayı: 2, 2021, s. 1057-1100 


\title{
DUTY FREE SHOPS IN TURKISH LAW AND COMPARATIVE LAW
}

\author{
(Research Article)
}

\begin{abstract}
The concept of "gümrüksüz satıs mağazası" is the Turkish adaptation of the "duty-free shop" concept, which is widely used in the world. The concept is commonly used as a "duty-free shop" without being translated into Turkish. These stores are sui generis businesses that are located at the customs entrance and exit and only those who fulfill certain conditions can shop. These stores also constitute an example of the mixed character of customs law reflected in practice. Because public law affects directly, not only the establishment, operation and inspection of these stores, but also some private law transactions made by these stores. However, regardless of the effect of public law, it is a fact that duty-free shops and their actions and transactions directly concern commercial law. In this article, the opening, activities, inspection and legal nature of duty free shops and important points regarding the commercial law dimension of the activities of the stores are mentioned. In this context, evaluations were made on whether the duty-free shops have the characteristics of branches, their transfer, monopoly right, seizure and pledge of the goods in the store. In addition, possible solutions to possible problems that may arise in practice are offered. The article also includes comparative law analysis on the subject. In this context, the situation in the legislation of some selected countries has been discussed in detail.
\end{abstract}

\section{Keywords}

Duty-Free, Duty-Free shops, Warehouse, Commercial business, Branch 


\section{GİRIŞ}

Ortaya çıkışı yirminci yüzyılın ikinci yarısına tekabül eden ve "dutyfree shop" adıyla bilinen gümrüksüz satış mağazaları, özellikle de demir perdenin yıkılması ve küreselleşme süreciyle ülkeler arası seyahatlerin yoğunluk kazanması ile birlikte, son yirmi yılda dünyada yaygınlık kazanmış ve bu durum hemen hemen tüm ülkelerin mevzuatlarında özel düzenlemelerin yapılması gereğini doğurmuştur. "Duty-free shop" sektörünün gerek ülkemizde ve gerekse dünyada yabancı sermaye girişinin yoğun olarak yaşandığ1, yüksek karlılık ve ciro getiren çok canlı bir sektör olduğu görülmektedir ${ }^{1}$. Bu çalışma gümrüksüz satış mağazalarının kurulması, faaliyete geçmesi, hukuki niteliği, denetimi konuları ile bu mağazaların ticaret hukuku açısından bir değerlendirmesini yapmayı amaçlamıştır. Dolayısıyla söz konusu mağazaların faaliyetlerinin vergi hukukuna ilişkin boyutu çalışmamızın kapsamı dışındadır. Bu bağlamda gümrüksüz satış mağazalarının başta ticari işletme ve şube nitelikleri üzerinde olmak üzere değerlendirmede bulunulacak, hukuki nitelikleri tespit edilmeye çalış1lacak; gümrüksüz satış mağazalarına ilişkin olarak tanınan tekel hakkı, mağazanın devre konu olması, mağazanın ve mağazadaki ürünlerin rehni ve haczedilmesi konularının irdelenmesi yapilacaktır.

\section{GÜMRÜKSÜZ SATIŞ MAĞAZALARI HAKKINDA GENEL BILLGILER VE KARŞILAŞTIRMALI HUKUKTA KONUNUN DÜZENLENIŞì}

\section{A. Gümrüksüz Satış Mağazası Kavramı, İşleyiş Mantığı ve Bu Mağazaların Ortaya Çıkışı}

Gümrüksüz satış mağazaları "alış ve satışında gümrük ve diğer vergilerin ödenmediği veya düşük nispetlerde ödendiği eşyaların satıldığı" mağaza şeklinde tanımlanabilir ${ }^{2}$. Bu mağazalar havaalanlarında ve hudut kapılarında, emniyet (pasaport) kontrolünden geçilmesinden sonra, gümrüksüz alan (tax-free zone) olarak ifade edilebilecek sahalarda kurulabilen; sattığ 1 malların nitelik ve nicelik itibarıyla, malların satıldığ 1 kişilerin de kural

1 Bu konuda bkz. Gümrüksüz ve Vergisiz Satış Mağazaları İşletmeciliği, Sektör Tanıtımı, Gümrük ve Ticaret Dergisi, 2013/1, s. 119. 2017 Y1l itibarıla dünya genelinde DFS'lerin perakende satış tutarının 64,6 milyar ABD Doları olduğu hakkında bkz. http://dfworldcouncil.com/what-is-duty-free-travel-retail/ (Erişim Tarihi: 10.06.2021).

2 Aksu, Mustafa: Gümrüksüz Satış Mağazalarında Pazarlama Organizasyonu, (Yayımlanmamış Doktora Tezi), İstanbul, 1989, s. 4. 
olarak dış hatlar yolcuları olarak sınırlandırıldığı, vergi hukuku anlamında birtakım ayrıcalıklı hükümlere tabi yerlerdir. Ülkeden ülkeye değişmekle birlikte genellikle giriş ve çıkışta ayrı ayrı gümrüksüz satış mağazaları bulunabileceği gibi gemi ve uçaklarda da bu mağazaların teşekkül etmesi imkân dâhilindedir. Bu mağazaların en önemli özelliği, mağazalarda satılan ürünler üzerinde birtakım vergi muafiyetleri tanınmak suretiyle, ürünlerin serbest dolaşıma girmiş eşyaya nazaran daha uygun olarak satılabilmesi ve bazen de serbest dolaşıma hiç girmemiş eşyaların yine uygun fiyatlarla satılabilmesidir $^{3}$. İlk ortaya çıktığı yer olan İrlanda'da, bu mağazaların açılma gayesi ülkenin iktisadi açıdan görece yoksul olan Shannon bölgesinin gelişimine katkı sağlanması idi ${ }^{4}$. Sonraki dönemlerde bu mağazaların yaygınlık kazanmasının ve böyle bir mağaza türüne ihtiyaç duyulmasının ardındaki temel nedenlerin ise; mağazalarda satılan ürünlerin kaçakçılığa müsait ürünlerden olması nedeniyle kaçakçılığa ve böylelikle kayıt dışı döviz çıkışına mâni olunması, haksız rekabetin önüne geçilmesi ve çeşitli avantajlar ve muafiyetler sağlanmak suretiyle ülkeye döviz kazandırılması olduğu söylenebilir ${ }^{5}$. Ancak tüm bu satış işlemlerinin mağazada alışveriş yapabilecek kişi başına belli limitlerle sınırlı olduğunu da belirtmek gerekir. Sağlanan bu mali avantajların ve satın alınabilecek ürünlerin belli bir sınıra tabi tutulmasının nedeni ise satılan ürünlerin ticari değil, tüketim amaçlı olması bir başka ifadeyle yolcu başına şahsi kullanım (personal use) ötesine geçememesinden kaynaklanmaktadır 6 .

Yine aralarında benzerlikler bulunmakla beraber gümrüksüz satış mağazalarının, serbest bölgelerde faaliyet gösteren işletmelerden farklılık arz ettiğini ifade etmeliyiz. Gerçekten de gümrüksüz satış mağazalarında yapılan satışlar, serbest bölgelere göre oldukça dar kapsamlı olup, bu mağazalarda ihracat ve ithalat işlemleri gerçekleştirilmemekte iken; serbest bölgelerde her türlü sınâ̂, ticari ve hizmetle ilgili faaliyetler yapılabilmektedir ${ }^{7}$. Yine

3 Bununla birlikte gümrüksüz satış mağazalarında satılan her ürünün serbest dolaşıma girmiş eşyaya göre daha uygun fiyatlı olmayabileceği, bu nedenle fiyat araştırması yapılmadan bu mağazalardan alışveriş yapılması durumunda belki de serbest dolaşımda daha ucuza satılan aynı ürünün çok daha pahalıya dahi alınabileceği yönünde bir değerlendirme için bkz. Duty Free Is Cheaper: Myth, Or Fact? (godsavethepoints.com) (Erişim Tarihi: 10.06.2021).

4 Sektör Tanıtımı, Gümrüksüz ve Vergisiz Satış Mağazaları (Duty-Free) İşletmeciliği, Gümrük ve Ticaret Dergisi, 2013/1, s. 118.

5 Aksu, s. 12.

6 Zoll online - Reisefreimengen (Erişim Tarihi: 06.09.2021).

7 Aksu, s. 13. Ayrıca bkz. Serbest Bölgeler Uygulama Yönetmeliği md. 10. (RG. 10.03.1993, S. 21520) 
gümrüksüz satış mağazalarında vergi muafiyeti satışa sunulan mallar bak1mından olup, mağazanın kendisinin vergi mükellefiyeti devam etmektedir ${ }^{8}$. Buna karşılık serbest bölgelerde faaliyet gösteren işletmelerin vergi hukuku anlamında çok önemli birtakım muafiyetleri söz konusudur?

Gümrüksüz satış mağazası terimi, gündelik hayatta sık kullanılmayan ve bu nedenle çoğu kimsede de herhangi bir çağrışım uyandırmayan bir kavramdır. Zira bu mağazalar tüm dünyada "duty-free shop" hatta sadece "duty-free" adıyla bilinir. Bazı ülkelerde "tax-free store", "export shop" olarak da adlandırılabilmektir. Ama kavramın hâkim kullanılışı kısaca "dutyfree" şeklindedir. Dünyada ilk duty-free shop 1951 yılında İrlanda'da Shannon Havaalanında Brendan O'Regan tarafından kurulmuştur ${ }^{10}$. Keza dolaylı olarak da olsa mevzuat anlamındaki düzenlemelerin yapılması da yine İrlanda' da da gerçekleşmiştir ${ }^{11}$.

Gümrüksüz satış mağazalarının yaygınlık kazanmasının ise sonraki zamanlarda gerçekleştiği görülmektedir. Nitekim Dünya Gümrük Örgütü (WCO), 16 Haziran 1960 tarihinde gümrüksüz satış mağazalarının münha-

8 Aksu, s. 14.

$9 \quad$ 15.06.1985 Tarihli ve 18785 sayılı Resmi Gazete'de yayınlanarak yürürlüğe giren Serbest Bölgeler Kanunu'nun geçici 3. maddesinin 5810 sayılı kanunun 7. maddesi ile değişik ikinci fikrasına göre, Avrupa Birliğine tam üyeliğin gerçekleştiği tarihi içeren yılın vergilendirme döneminin sonuna kadar serbest bölgelerde üretim faaliyetinde bulunan mükelleflerin bu bölgelerde imal ettikleri ürünlerin satışından elde ettikleri kazançları ile serbest bölgelerde, bakım, onarım, montaj, demontaj, elleçleme, ayrıştırma, ambalajlama, etiketleme, test etme, depolama hizmeti alanlarında faaliyette bulunan ve hizmetin tamamını Türkiye'de yerleşmiş olmayan kişilerle, işyeri, kanuni ve iş merkezi yurt dişında bulunanlara veren hizmet işletmelerinin, söz konusu hizmetlere konu malların serbest bölgelerden Türkiye'ye herhangi bir şekilde girişi olmaksızın yabancı bir ülkeye gönderilmesi şartıyla bu hizmetlerden elde ettikleri kazançları gelir veya kurumlar vergisinden müstesnadır.

10 Seely, Antony: Duty-free shopping, House of Commons Library Research Paper 99/74, 1999, s. 7 (Erişim Tarihi: 12.06.2021); Brendan O’Regan | The Times (Erişim Tarihi: 12.06.2021); Kaliç, Özkan: Gümrüksüz Satış Mağaza Faaliyetlerinin Bilgisayar Desteğinde Yürütülmesi ve Bir Uygulama Örneği, (Yayımlanmamış YL Tezi), İstanbul, 1992, s. 3.

11 Gerçekten de, İrlanda parlamentosu tarafindan 18 Mart 1947 tarihinde kabul edilen The Custom Free Airport Act bu konuda tüm dünyaya öncülük teşkil etmiştir. Kanun metni için bkz. Customs-Free Airport Act, 1947 (irishstatutebook.ie) (Erişim Tarihi: 10.06.2021). Bu kanun daha sonra 25 Kasım 1958 yılından yapılan değişikliklerle Customs-Free Airport (Amendment) Act of 1958 adını almıştır. Söz konusu düzenlemenin 9. maddesi ile gümrüksüz satış mağazaları daha açık bir hukuki dayanağa kavuşmuştur; bkz. Customs-Free Airport (Amendment) Act, 1958 (irishstatutebook.ie) (Erişim Tarihi: 10.06.2021). 
sıran deniz limanlarında ve gümrük havalimanlarında işletilebilmesine ve bu tür mağazalarda malların gümrüksüz ve vergisiz olarak ve yalnız yurt dışına seyahat edenlere satışına izin verilmesi gerektiğine dair bir tavsiye kararı yayınlamıştır ${ }^{12}$. Mağazaların yaygınlık kazanması da bu karardan sonrasına dayanmaktadır. Ülkemizde de ilk gümrüksüz satış mağazalarının kurulması bu gelişmeleri takip ederek, 1965 yılında gerçekleşmiştir ${ }^{13}$.

\section{B. Karşılaştırmalı Hukukta Gümrüksüz Satış Mağazalarına İlişkin Düzenlemeler}

Gümrüksüz satış mağazaları ile ilgili olarak karşılaştırmalı hukuk incelemesi yapmak, mevzuatımızdaki düzenlemelerin anlaşılabilmesi açısından bize 1şık tutacaktır. Karşılaştırmalı hukuk incelememizi yaparken belirli birkaç ülkeyle sınırlı kalınmamış olup, mümkün olduğunca farklı hukuk çevrelerinin ve ayrıca sektörün güçlü olduğu birtakım ülkelerin hukuki düzenlemelerine yer verilmiş, böylelikle farklı çözümlerin görülebilmesine olanak sağlanmak amaçlanmıştır. Keza karşılaştırmalı hukuk incelemesi yaparken seçilen ülkelerin tesadüfi olarak belirlenmediğini de belirtmek gerekir. Nitekim 2017 yılı istatistiklerine göre dünya genelinde gümrüksüz satış mağazalarında yapılan satışların \%49,2'si Asya-Pasifik olarak adlandırılan ülkelerde gerçekleşmiştir ${ }^{14}$. Bu nedenle mezkûr bölgede yer alan Avustralya, Çin Halk Cumhuriyeti ve Tayvan hukuklarındaki düzenlemelere yer verilmiştir. Anglo-Sakson yaklaşımını temsilen Amerika Birleşik Devletleri ve Kanada hukuku ile Brexit süreci ile birlikte ayrıca hususiyet arz etmesi nedeniyle Birleşik Krallık hukukundaki düzenlemeler de incelenmiştir. Pek çok noktada hukukumuza kaynaklık teşkil eden İsviçre hukuku ve Avrupa Birliği mevzuatındaki düzenlemelerin yanı sıra $\mathrm{AB}$ ile olan yakın ilişkileri nedeniyle Norveç'in benimsediği sistem de çalışmamızda irdelenmiş bulunmaktadır.

12 Söz konusu kararın, o dönem İsviçre'yi uluslararası ticaret ve ulaşım konularında rekabet edemez duruma düşürmemek adına İsviçre Federal Konseyi tarafından da benimsendiğine ilişkin olarak bkz. Botschaft zum Bundesgesetz über den Einkauf von Waren in Zollfreiläden auf Flughäfen, 12. März 2010, https://www.admin.ch/opc/de/federalgazette/2010/2169.pdf, s. 2171. (Erişim Tarihi: 14.06.2021).

13 Gümrüksüz ve Vergisiz Satış Mağazaları İşletmeciliği, Sektör Tanıtımı, Gümrük ve Ticaret Dergisi, 2013/1, s. 119. Ülkemizde ilk olarak girişte Tekel ve Türksan, çıkışta Tekel ve Setur mağaza açmış ve daha sonra bunlara yenileri eklenmiştir; bkz. Kaliç, s. 3.

14 Global Travel Retail Change 2018 v 2017, PowerPoint Presentation (dfworldcouncil.com) (Erişim Tarihi: 06.09.2021). 


\section{1. İsviçre Hukuku'ndaki Düzenlemeler}

İsviçre'de gümrüksüz satış mağazalarına (Zollfreiläden) ilişkin olarak Gümrük Kanunu (Zollgesetz-ZG) md. 17 hükmü özellikle zikredilmelidir ${ }^{15}$. Hemen belirtelim ki, ZG'nin bu maddesi, 17 Aralık 2010 tarihli Havaalanlarında Bulunan Gümrüksüz Satış Mağazalarında Mal Alımlarına İlişkin Federal Kanun ile mevcut halini almıştır. ZG Art. 17 Abs. 1 hükmüne göre Federal Maliye Bakanlığı (EFD), hava meydanlarında sürekli olarak faaliyet gösteren gümrük dairelerinin bulunduğu havaalanı işletmecilerine gümrüksüz satış mağazası işletme hususunda yetki verilebilecektir. Görüldüğü gibi bu düzenleme ile gümrüksüz satış mağazası işletmeciliği yapmak üzere lisans verilmesi havaalanı işletmecilerine tanınmıştır. ZG Art. 17 Abs. 3 hükmüne göre ise Federal Gümrük İdaresi (EZV), havac1lık şirketlerine ya da diğer şirketlere gümrük havalimanlarında veya yakınlarında, uçakta açık büfe hizmetlerinin sağlanması için gümrüksüz malları depolama ve bunları yurtdışı uçuşlara hazırlamak için kullanma yetkisi verebilir. Her halükârda bu izinlerin verilebilmesi için gerekli güvenlik ve kontrol önlemlerinin sağlandığının tespiti gerekmektedir (ZG Art.17 Abs. 3). Giden ve gelen yolcu$\operatorname{ların}^{16}$ bu mağazalardan hangi ürünleri satın alabileceği ise Federal Konsey tarafindan belirlenecektir (ZG Art. 17 Abs. 2).

1 Kasım 2006 tarihli Gümrük Yönetmeliği'nin (Zollverordnung-ZV) 69. maddesi ise "Gümrüksüz Satış Mağazaları ve Gemide Büfe Hizmetleri" başlığını taşımakta ve birinci fikrasında mağazalarda yurt dışına giden ve yurt dışından gelen yolculara hangi ürünlerin satılabileceğini hükme bağlamaktadır ${ }^{17}$. İkinci fıkrasında ise gümrüksüz satış mağazalarındaki depolama işlemlerinin açık gümrük antrepo hükümlerine göre gerçekleştirileceği ifade edilmiştir. Gümrüksüz satış mağazası işletmeciliğinin hukuki dayanağını da bu hüküm teşkil etmektedir. ZG Art. 54'e göre açık gümrük antreposu işletebilmek için Federal Gümrük İdaresi’nden izin almak gerekmektedir. Aynı maddeye göre bu iznin verilebilmesi için başvuru sahibinin İsviçre'de yerleşik olması ve açık gümrük antreposunun hukuka uygun bir şekilde çalışaca-

15 Kanun metni için bkz. https://www.admin.ch/opc/de/classified-compilation/20030370/ index.html\#a17 (Erişim Tarihi: 14.06.2021).

16 Yurtdışından gelen yolcuların da mağazalardan alışveriş yapabilmesi, 2010 tarihli kanun ile getirilen yeniliklerden birisidir. Bu değişiklikten önce sadece giden yolcuların mağazalardan alışveriş yapabilmesine izin verilmekte idi; bkz. Botschaft zum Bundesgesetz über den Einkauf von Waren in Zollfreiläden auf Flughäfen, 12. März 2010, https://www.admin.ch/opc/de/federal-gazette/2010/2169.pdf, s. 2175.

17 Yönetmelik metni için bkz. https://www.admin.ch/opc/de/classified-compilation/ 20052713/index.html (Erişim Tarihi: 14.06.2021). 
ğına ilişkin bir garanti vermesi şartları aranmaktadır. Verilen bu izin şarta bağlı bir izindir ve belirli riskli mallar bakımından da istisnaları mevcuttur (Art. 54 Abs. 3). Gümrük Yönetmeliği (ZV) Art. 158 ise başvurucunun ciddi suçlar işlemesi ya da müteaddit defalar federal kanunları ihlal etmiş olmasının hukuka uygun çalışmanın garanti edilemediği anlamına geldiğini belirtmektedir. Art. 159 hükmüne göre de lisans sahibi ZG Art. 54'ün şartlarını artık sağlamıyorsa, lisans belgesindeki şartlara aykırı hareket ediyorsa ve lisans sahibinin suç işlemesi durumunda lisansın geri alınması söz konusu olabilecektir.

\section{Kanada Hukukundaki Düzenlemeler}

Kanada'da gümrüksüz satış mağazalarına ilişkin hukuki düzenlemeler Gümrük Kanunu'nun 164. maddesine dayanarak 1986 yılında çıkartılan SOR $^{18} 86 / 1072$ sayll Duty Free Shop Regulations'da yer almaktadır ${ }^{19} . \mathrm{Bu}$ yönetmeliğin 3. maddesinde gümrüksüz satış mağazası açılabilmesi için gerekli şartlara yer verilmiş bulunmaktadır. Buna göre anonim şirketler ile gerçek kişilerin gümrüksüz satış mağazası kurabilmesine imkân tanınmıştır. Bir anonim şirketin, gümrüksüz satış mağazası kurabilmesi için şirketin Kanada'da kurulu olması gerekir (md. 3/3, a). Ayrıca şirketin tüm hisselerinin bir Kanada vatandaşı ya da Kanada'da daimi ikamet eden bir kişiye, hisselerinin bir Kanada vatandaşı ya da Kanada'da daimi ikamet sahibi bir kişiye ait olduğu başka bir anonim şirkete veya Kanada vatandaşı, Kanada'da daimi ikameti olanla birlikte bir anonim şirkete birlikte ait olması gerekmektedir (md. 3/3, b). Ayrıca Kanada vatandaşı ile Kanada'da daimî ikameti bulunan kişinin de iyi karakterli olması, ana ikametgâhının Kanada'da bulunması ve mağaza açma başvurusundan önceki y1lda en az 183 günü Kanada'da geçirmiş olması gibi şartları taşıması şarttır (md. 3/4, a, b, c bentleri). Önemle belirtelim ki, bu son şartları taşıyan gerçek kişilerin de mağaza açma başvurusunda bulunmasına olanak tanınmıştır (md. 3/5).

Yönetmeliğin 3/6 hükmünde bir gümrüksüz alanda birden fazla mağaza işletmenin mümkün olmadığı hükme bağlanmıştır. Yönetmeliğin 4. maddesi ise mağaza açma başvurusunda bulunacaklardan teminat alınmasını öngörmektedir. Bu miktar her halükârda on bin Kanada dolarından az olmayacak ve gerekli görülmesi halinde artırılabilecektir. Yönetmeliğin 6. maddesine göre verilen mağaza açma izinlerinin geçerlilik süresi 10 yıldır.

18 Statutory orders and regulations.

19 https://laws-lois.justice.gc.ca/eng/regulations/sor-86-1072/FullText.html (Erişim Tarihi: 14.06.2021) 
Yönetmeliğin 8. maddesi verilen iznin iptal edilmesi ve askıya alınmasi hallerini ayrıntılı olarak düzenlenmiş bulunmaktadır. Buna göre mağaza işletenin iflas etmesi, mağazanın bulunduğu işyerinin tapusunu devretmesi ya da kira sözleşmesini yenilememesi veya mağaza sahibinin talep etmesi üzerine mağaza açma ve faaliyet izni iptal edilecektir. Mağaza işletenin borçları nedeniyle tasfiyeye tabi tutulması, kanun ve sair düzenlemelere aykırı hareket etmesi, dürüst olmayan davranışlarda bulunması, satılan malların hacminin mağazanın işleyişini garanti etmek için yeterli olmaması, o bölgede mağazaya artık ihtiyaç kalmaması gibi durumlar ise iznin iptal veya askıya alınması nedenleri olarak kabul edilmiştir. Bunun haricinde lisans devri ise söz konusu olmayıp, lisansı devretmek isteyen işleticinin bunun iptali için başvurması gerekmektedir ${ }^{20}$. Yine gümrüksüz satış mağazası işleteninin gerçek kişi olması ve ölmesi durumunda da mirasçılarına bildirim yükümlülüğü getirilmekte, mağaza geçici olarak kapatılmakta ve mirasçılara işletmeyi mevzuata uygun hale getirmeleri için 30 gün süre verilmektedir ${ }^{21}$.

Yönetmeliğin 18. maddesinin birinci fikrası ise gümrüksüz satış mağazasındaki malların mülkiyetinin yalnızca Kanada'dan ayrılmak üzere olan kişilere satış yoluyla devredilebileceğini hükme bağlamıştır.

Görüldüğü gibi Duty Free Shop Regulations gümrüksüz satış mağazalarına ilişkin oldukça ayrıntılı düzenlemeler içermektedir. Bu düzenlemeler özellikle de devir ve lisansın son bulması noktalarında ülkemizdeki düzenlemelerden farklı olup, daha koruyucu bir mantıkla hazırlanmıştır.

\section{Tayvan Hukuku'ndaki Düzenlemeler}

Tayvan güçlü bir ekonomik yapıya sahip olmasının yanı sıra, hukuki anlamda üzerinde (özellikle de uluslararası hukuk konusunda) pek çok mukayeseli bilimsel çalışma yapılan bir ülkedir. Tayvan'ın hukuk sisteminin Kita Avrupası ve Anglo-Amerikan hukuk sistemlerinin ikisinin de etkisi altında bulunması nedeniyle karşılaştırmalı hukuk disiplini açısından karma hukuk sistemlerine dâhil olduğu söylenebilir. Tayvan hukukunda konuyla ilgili düzenleme 20.02.1970 tarihli Gümrüksüz Satış Mağazalarının Kurulması ve Yönetilmesine Dair Yönetmelik ile ele alınmıştır ${ }^{22}$. Hemen belir-

20 https://www.cbsa-asfc.gc.ca/publications/dm-md/d4/d4-3-2-eng.html (Erişim Tarihi: 15.06.2021).

21 https://www.cbsa-asfc.gc.ca/publications/dm-md/d4/d4-3-2-eng.html (Erişim Tarihi: 15.06.2021).

22 https://law.moj.gov.tw/ENG/LawClass/LawAll.aspx?pcode=G0350036 (Erişim Tarihi: 15.06.2021). 
telim ki mezkûr yönetmelik en sonuncusu 16.06.2020 tarihinde olmak üzere toplamda $27 \mathrm{kez}$ değişikliğe uğramıştır. Yönetmeliğin 3. maddesine göre iki tür gümrüksüz satış mağazası bulunmaktadır. Bunlardan ilki, uluslararası bir havalimanı ya da liman içerisindeki belli bir bölgede açılan; ikincisi ise, şehir merkezinde ama uluslararası havalimanı ya da liman yakınında olup, gümrük idaresince yetkilendirilmiş gümrüksüz satış mağazası olarak karş1mıza çıkmaktadır. Bunlardan ilki, giden, gelen ve transit yolculara mal satmaya yetkili iken, ikincisi ise giden turistlere ve yolculara mal satma konusunda yetkilidir (md. 4).

Gümrüksüz satış mağazalarının kurulması ise yönetmeliğin 9. maddesinde hükme bağlamıştır. Oldukça ayrıntılı olan bu maddede gümrük satış mağazası kurmak için asgari sermayesi elli milyon yeni Tayvan doları olan sınırlı sorumlu şirket olma, şirketin faaliyet konusunun turistlere satış olması ve mağaza ile birlikte antrepo da açılmasının gerekli olması gibi şartlar arandığ 1 görülmektedir. Mağaza açmak için verilen ruhsat ise 3 yıl için geçerlidir ve 3 yıl daha uzatılması mümkündür (md. 11). Ancak sürenin kendiliğinden yenilenmesi mümkün olmayıp, mağaza sahibinin sürenin son bulmasından 2 ay önce başvuruda bulunması gerekmekte, yapılan yeniden değerlendirme neticesinde yeni bir lisans verilmektedir (md. 11). Mağazaların mutlaka bir antrepoya sahip olmaları gerekmektedir (md. 17).

\section{4. Çin Halk Cumhuriyeti Hukuku'ndaki Düzenlemeler}

Çin Halk Cumhuriyeti'nde konu ile ilgili olarak 28 Kasım 2005 tarihli Çin Halk Cumhuriyeti Genel İdaresi 132 numaralı emri ile yayınlanan, 1 Ocak 2006 tarihinde yürürlüğe giren Gümrüksüz Satış Mağazaları ve Gümrüksüz Ürünlerin Gözetimi ve Kontrolüne İlişkin Önlemler yürürlüğe konulmuştur. Bu önlemler 29 Mayıs 2018 tarihinde Gümrük Genel İdaresinin 240 numaralı emri ile güncellenmiş bulunmaktadır ${ }^{23}$. Bu önlemlerin 7. maddesine göre gümrüksüz satış mağazası kurmak isteyen işletmelerin tüzel kişiliklerinin bulunması, gümrüksüz emtia için satış yeri ve denetim deposunun bulunması gerekmektedir. Görüldüğg̈ gibi satış mağazası kurmak için tüzel kişiliğe sahip olmak gerekmekte, dolayısıyla gerçek kişilerin mağaza kurmaları mümkün olmamakta ancak tüzel kişiliğe sahip şirketler dışında diğer tüzel kişilere de mağaza açmak için başvuruda bulunabilme imkânı tanınmaktadır. 28. maddeye göre de mağazaların işletme haklarının kiralanması ya da devri yasaklanmıştır.

23 http://search.chinalaw.gov.cn/law/detail?LawID=405204 (Erişim Tarihi: 15.06.2021). 


\section{Norveç Hukukundaki Düzenlemeler}

Norveç, $\mathrm{AB}$ üyesi olmamasına rağmen $\mathrm{AB}$ ülkeleri ile çok sıkı ticari ilişkileri bulunan bir ülkedir. Bu bakımdan Norveç hukukundaki düzenleme de konumuz açısından önem taşımaktadır. Norveç hukukunda gümrüksüz satış mağazaları, Gümrük Yükümleri ve Hareketleri Hakkında Kanun ${ }^{24}$ Yönetmeliği'nde düzenlenmiştir ${ }^{25}$. Bu yönetmeliğin 4-23-11. maddesine göre serbest dolaşım izni olmayan ürünler havaalanındaki vergisiz mağazalardan, yurt dişına seyahat etmek isteyen kişilerce (malların ihraç edilmiş olması şartı ile) satın alınabilecektir. Yönetmelik md. 4-30-2/1 hükmüne göre gümrük müdürlükleri bir işletmeye, bir havalimanında C Tipi Antrepo (md. 4-3013) hükmünde olmak üzere gümrüksüz ve vergiden muaf bir mağaza kurma ve işletme yetkisi verebilir. Havaalanında gümrüksüz satış mağazası açılabilmesi için havaalanının uluslararası statüye sahip olması ve mağazanın sadece yurtdışına giden ve yurtdışından gelen yolcuların ulaşabileceği şekilde konumlanmas1 gerekir (md. 4-30-13/4). Yönetmeliğin 3-1-18/2 hükmüne göre gümrüksüz satış mağazası açılabilmesi için başvuru sahibinin (kural olarak, zira gümrük idaresi buna istisna getirebilir) ticari işletme olarak sicile kayıtlı olması, işletmenin yönetici ve temsilcilerinin geçen 3 yıl içinde vergi ve gümrük mevzuatını ciddi bir şekilde ihlal etmemiş olmaları, işletmenin bir iç kontrol sistemine sahip bulunması gerekmekte olup; yönetmelik md. 3-1-18/4 hükmü uyarınca verilen izinlerin geçerlilik süresi 5 yıl olarak belirlenmiştir. Başvuru yapabilme yetkisine sahip ticari işletme kavramı ile neyin kastedildiğine gelince; yönetmelik md. 3-1-20 hükmüne göre bununla Norveç'te mukim ve Norveç ticari işletmeler siciline kayıtlı işletmeler anlaşılmalıdır. Bununla birlikte, merkezi Norveç dışında bulunan havayolu ya da nakliye şirketlerine de, bölgesel ofislerinin bulunması kaydıyla başvuru izni verilebilecektir. Ayrıca AB içerisinde eşdeğer statüdeki işletmelerin bu anlamda gerekli şartları taşıdığı da kabul edilmektedir (md. 3-120/3). Son olarak izin şartlarına aykırılık veya hukuka aykırı bir durumun tespiti halinde verilen iznin geçici ya da sürekli olarak geri alınabileceği de belirtilmelidir (md. 3-1-19).

\section{Avustralya Hukukundaki Düzenlemeler}

Avustralya hukukunda gümrüksüz satış mağazalarına ilişkin temel düzenlemeler Customs Act of 1901, Part V, Section 79-101 arasinda ifade-

\footnotetext{
21 Aralık 2007 tarihli ve 119 sayılı kanun.

Yönetmelik metni için bkz. https://www.toll.no/contentassets/eb096d765fd3460c9415 b6a3d158aec1/oversettelse-av-tollforskriften-siste-endringer-per-1.-mai-2020.pdf (Erişim Tarihi: 15.06.2021).
} 
sini bulan antrepolara ilişkin kısımda hükme bağlanmıştır ${ }^{26}$. Bu kısım hükümlerinden özellikle de Section 96A ve 96B hükümleri konumuzla doğrudan ilgilidir. Bunun yanı sıra Customs Regulation of 2015 hükümleri de önem taşımaktadır ${ }^{27} .2015$ Tarihli bu yönetmeliğin antrepolarla ilgili 6.kısmının $39 \mathrm{vd}$. maddelerinde gümrüksüz satış mağazaları ile ilgili hükümler bulunmaktadır. Ayrıca bütün bu hükümlerin uygulamasının nasıl gerçekleşeceği konusunda gümrüksüz satış mağazası işletenlere yardımcı olmak üzere Avustralya Hükümeti Göç ve Sınır Koruma Bürosu tarafından da "Duty-Free Operators' Guide" adında bir rehber yayınlanmış bulunmakta-

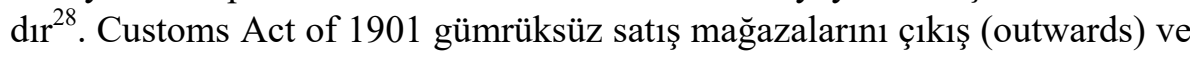
giriş (inwards) gümrüksüz satış mağazası olmak üzere ikiye ayırmıştır (Sec. 96A/96B). Bu mağazalar antrepo hükmündedir. Kanunun 81. maddesi genel olarak antrepo lisansının kimlere verileceğini hükme bağlamıştır. Bu maddeye göre gerçek kişiler, ortaklıklar (partnerships) ve şirketler (companies) antrepo lisansı alabilmek için başvuruda bulunma hakkına sahiptir. Bununla birlikte gümrük denetmeni; gerçek kişinin, ortakların ya da şirket yönetici, çalışan ya da ortaklarının şahsından kaynaklanan sebepleri gerekçe göstererek lisans başvurusunu reddedebilecektir. Bu kapsamda başvuru tarihinden önceki on yıl içerisinde gümrük mevzuatına aykırılıktan dolayı ceza alınmas1, İngiliz Milletler Topluluğu (Commonwealth) bünyesinde bir yıldan uzun süreli bir mahkûmiyet kararının varlığı, bu kişilerin iflas etmiş olup da halen ibra edilmemiş olması (undischarged bankrupt), yanlış ve yanıltıcı beyanlarda bulunulduğunun tespit edilmesi ret nedeni olduğu gibi, bu hallerin sonradan gerçekleşmesi de verilen lisansın iptali için neden olabilecektir. Lisans sahibinin gerçek kişi olması halinde, ölümü durumunda lisanstan doğan haklar onun kanuni temsilcisine intikal edecektir (Sec. 89). Avustralya'da gümrüksüz satış mağazası işletecek kişilerin sadece gümrük idaresi tarafindan lisans almaları yetmemekte ayrıca ilgili eyalet ticaret kanunları tarafindan öngörülen izinler ile birlikte Avustralya Vergi Dairesi'nden vergiden muaf mal satma iznini de almaları gerekmektedir ${ }^{29}$. Bir diğer önemli durum da sadece giriş ya da çıkış mağazası için alınan lisansın (bunlar eğer bitişik

26 Customs Act 1901'in ilgili hükümleri için bkz. Customs Act 1901 (legislation.gov.au) (Erişim Tarihi: 15.06.2021).

27 Customs Regulations 2015 için bkz. Customs Regulation 2015 (legislation.gov.au) (Erişim Tarihi: 15.06.2021).

28 Duty-Free Operators' Guide, Australian Goverment Department of Immigration and Border Protection, July, 2017, Duty Free Shop Operators' Guide July 2017 (abf.gov.au) (Erişim Tarihi: 15.06.2021).

29 Duty-Free Operators' Guide, s. 5. 
değilse) tek bir mağaza için geçerli olduğu hususudur ${ }^{30}$. Bu husus Customs Regulation of 2015 md. 39 ve md. 60'da ayrıca belirtilmiştir.

\section{Amerika Birleşik Devletleri Hukukundaki Düzenlemeler}

Amerika Birleşik Devletleri hukukunda gümrüksüz satış mağazaları Sinıf 9 Antreposu olarak anılmaktadır. Bu mağazalar Code of Federal Regulations-CFR'nin “Gümrük Vergileri” adlı 19.başlığının 1.bölümünün, "Gümrük Antrepoları, Konteyner İstasyonları ve Buralardaki Ticaretin Kontrolü" başlıklı 19. kısmında, "Gümrüksüz Satış Mağazaları" adı altında $\S \S 19.35-19-39$ arasında düzenlenmiştir ${ }^{31}$. Bu mağazaların Sınıf 9 Antreposu olarak adlandırılmasının nedeni ise 19 CFR Part 19'un $\S 19,1$ hükmünde yer alan gümrük antrepolarına ilişkin sınıflandırmada 9. sınıf antrepo olarak gösterilmesinden kaynaklanmaktadır ${ }^{32}$.

Gümrüksüz satış mağazalarının nasıl kurulacağına ilişkin olarak $\S \S$ 19.35 hükmünde gümrüksüz satış mağazalarının koşullu gümrüksüz malların, gerçek kişilerin dış ticaret bölgeleri de dâhil olmak üzere gümrük bölgesinden uçak ya da gemi ile ayrılması veya doğrudan araçla veya yaya olarak komşu bir ülkeye gitmesi esnasında, ihracının sağlanması amacıyla kurulabileceği belirtilmiştir [ $\S \S 19.35$ (a)]. Gümrüksüz satış mağazaları, gümrüksüz mağazada satışa sunulan malların alıcısının gümrük bölgesinden ayrıldığ 1 giriş limanı içerisinde ya da ayrılmanın gerçekleştiği çıkış yeri itibarıyla 25 kara mili içerisinde, havaalanlarında ise herhangi bir giriş noktası ya da bunun 25 kara mili içerisinde kurulabilir ya da faaliyet gösterebilir $[\S \S 19.35(\mathrm{~b})]$.

Gümrüksüz satış mağazalarının kurulma usulü ile ilgili hükümlerin $\S \S$ 19.2'de yer aldığını görmekteyiz. Gümrüklü antrepo tesisi kurmak isteyen malik veya kiracı, antreponun bulunduğu yere en yakın liman müdürüne ${ }^{33}$ tesisi tanımlayan ve hangi sınıfta bir antrepo kurmak istediğini içeren yazılı başvuruda bulunur [ $\S \S 19.2$ (a)]. Liman müdürlügü gerek duyması durumunda başvuru sahibinden antreponun yönetici ve çalışanları ile antrepoda doğrudan ya da dolaylı olarak iktisadi menfaati bulunan kişilerin listesini talep edebilir [§§ 19.2 (a)]. Bunun haricinde $\S \S 19.2$ (b) bendinde sinıf 9

\footnotetext{
30 Duty-Free Operators' Guide, s. 6.

31 Söz konusu düzenleme için bkz. eCFR :: Title 19 (federalregister.gov) (Erişim Tarihi: 16.06.2021).

32 Bu hüküm gümrük antrepolarını 11 sınıfa ayırmış bulunmaktadır.

33 Liman kavramı geniş bir şekilde anlaşılmalı ve havaalanı gibi yerler de bu kapsamda değerlendirilmelidir.
} 
antrepoları için özel birtakım düzenlemelerle karşılaşıyoruz. Başvuru esnasında verilecek belgelerle ilgili olan bu özel düzenlemeler arasında mağazanın açılacağı eyalet yetkilisinden alınan uygunluk beyanı ile teminat göstermeye ilişkin hükümler özellikle zikredilmelidir. Liman müdürlügü başvuru sahibinin niteliği, karakteri ve tecrübesi ile ilgili hususların bir gümrük yetkilisi tarafından soruşturulmasını talep edebilecektir [§§ 19.2 (f)]. Bu anlamda başvuru sahibinin kişisel geçmişi, finansal ve ticari kayıtları, kredi bilgileri ve şahsi referansları araştırılabilecektir. Hatta başvuru sahibinin ve mağazada çalışacak kişilerin parmak izlerinin alınması da talep edilebilecektir. Liman müdürünün başvurunun reddine ilişkin gerekçeli kararı, aynı zamanda yetkili gümrük idaresinin nihai bir tespiti niteliğinde olacaktır [§§ $19.2(\mathrm{~g})]$.

Burada mağazanın bulunduğu yerin kira sözleşmesi ile kiralanmak suretiyle işletilmesi durumunda mağaza sahibine yükletilen tasfiye yükümlülüğünü de ayrıca belirtmek gereği duymaktayım. Buna göre mağaza sahibi kira süresinin sona ermesinden önce mağazada yer alan malları, her türlü borçtan ari olarak en yakın mağazaya nakletmek ya da bunu yapamıyorsa biran önce gümrük mevzuatına uygun bir şekilde elden çıartmakla yükümlüdür [§§ 19.2 (b)].

\section{Avrupa Birliği Hukuku Düzenlemeleri ve Avrupa Birliği Üyesi Ülkelerdeki Durum}

Gümrüksüz satış mağazaları bir dönem $\mathrm{AB}$ ülkelerinde oldukça canlı tartışmalara sebebiyet vermiştir. Bunun nedenini ise ECOFIN (Economic and Financial Affairs Council) tarafından 11 Kasım 1991 tarihinde alınan ve 1 Temmuz 1999 tarihi itibarıyla AB sınırları içerisinde gümrüksüz satışlara son verileceğine ilişkin karar teşkil etmektedir. Bu kararın ardından, doksanlı yıllar boyunca Avrupa Birliği ülkelerinde gümrüksüz satış mağazaları gündemde kalmış, mesele çeşitli platformlarda enine boyuna tartışılmıştır ${ }^{34}$. Ancak tüm lobi çalışmalarına rağmen bu karardan dönülmediğini de belirtmek gerekir. Bununla birlikte 1 Temmuz 1999 yılından itibaren AB içinde gümrüksüz satışlar kaldırılmış olsa da, $\mathrm{AB}$ dışı yerlere yapılan seyahatler için gümrüksüz satışlar devam etmektedir ${ }^{35}$. Gümrüksüz satış mağazaları ise

34 Bu konudaki tartışmaların ayrıntılı bir panoraması için bkz. Seely, s. 13 vd. AB Komisyonu'nun 24 Eylül 1997 tarihli "Duty-Free Sales-The Facts" adlı basin notunda gümrüksüz satışların neden sona ermesi gerektiği ayrıntılı olarak savunulmuştur; bkz. https://ec.europa.eu/commission/presscorner/detail/en/MEMO_97_82. (Erişim Tarihi: 16.06.2021).

35 Duty-Free Sales-The Facts. 
bir nevi başka hukuki niteliğe bürünmek suretiyle varlığını devam ettirmektedir. Gerçekten de 1 Temmuz 1999 tarihinden sonra da bu mağazalar AB içi seyahatlerde de tıpkı AB dışı seyahatlerde yapılan satışlarla aynı fiyat üzerinden satışlar yapmakta; varış noktasına ve yolcunun milliyetine bakılmaksızın herkes duty-free fiyatlardan yararlanmakta, bu durum ise AB ülkelerinde "travel value" olarak adlandırılmaktadır ${ }^{36}$. Böylelikle sıradan bir perakende satış mağazası ile gümrüksüz satış mağazalarının iç içe geçmiş olduğu görülmektedir. $\mathrm{AB}$ ülkelerinde bu tip mağazaların kurulması sıklıkla havaalanı işletmecisi ile perakendeci arasında yapılan, gelirden yüzdelik olarak pay verme esasına dayalı ve genellikle de (gümrüksüz ürünler bakımından) münhasırlık hakkı tanıyan bir imtiyaz sözleşmesine dayanmakla beraber; söz konusu mağazalar havaalanı işletmecisi ile joint venture anlaşması yapılması şeklinde, havaalanı işletmecisinin bizzat kendisinin işletmesi şeklinde de işletilebilmektedir ${ }^{37}$. Bu tip mağazaların aynı zamanda depo sahibi olmaları da işin mahiyeti gereği zorunluluk arz ettiğinden, doğal olarak mağaza işletenler $\mathrm{AB}$ gümrük mevzuatının antrepo kurulmasına ilişkin hükümlerine de tabi olacaktır. Bu konuyla ilgili olarak Birlik Gümrük Kodu şeklinde tercüme edebileceğimiz Union Customs Code-UCC Art. 211/1 uyarınca kişilerin antrepo kurabilmesi ilgili gümrük idaresinden izin alınması şartına bağlanmış; UCC Art. 211/3 (a) bendine göre de antrepo kurucularının AB sınırları içerisinde yerleşik olmaları gerektiğinin altı çizilmiştir ${ }^{38}$.

\section{Birleşik Kralık Hukukundaki Düzenlemeler}

Birleşik Krallık’ta Brexit süreci ile birlikte gümrüksüz satış mağazalarının yeniden önem kazandığ 1 ve hatta popülerlik kazandığı görülmektedir. Birleşik Krallık'ta gümrüksüz satış mağazalarına ilişkin temel hukuki dü-

36 Bu yöntemde perakendeci, gümrük vergisinden muaf ürünlerle aynı ya da benzeri fiyatları sunabilmek için vergi maliyetini bizzat üstlenmektedir; bkz. EC Case No COMP/ M.5123 Autogrill/World Duty Free, Notification of 7 April 2008 pursuant to Article 4 of Council Regulation No 139/2004, s. 3. Hemen belirtelim ki, gümrüksüz satışların kaldırılmasının AB ülkelerinin rekabet gücünü diğer ülkelere göre zayıflattığı ve yeniden düşünülmesi gerektiği The European Travel Retail Confederation tarafindan siklıkla gündeme getirilmektedir. Özellikle de Covid-19 salgın hastalığı nedeniyle AB havaalanlarının desteklenmesi amacıyla en azından gelen yolculara bu imkânın tanınması gerektiği ileri sürülmektedir; bkz. ETRC - Arrivals Duty Free (Erişim Tarihi: 16.06.2021).

37 Case No COMP/M.5123 Autogrill/ World Duty Free, Notification of 7 April 2008 pursuant to Article 4 of Council Regulation No 139/2004, s. 3 ve ayrica dn. 5.

389 Ekim 2013 tarihli ve 952/2013 sayılı AB Tüzügü ile yürürlüğe giren Union Customs Code- UCC metni için bkz. UCC - Legislation | Taxation and Customs Union (europa.eu) (Erişim Tarihi: 30.06.2021). 
zenlemeler olarak The Customs and Excise Management Act of 1979 adl kanun ile The Excise Goods (Export Shops Regulations) 2000 ve The Warehousekeepers and Owners of Warehoused Good Regulations 1999 adl yönetmelikleri zikredebiliriz. Brexit süreci sonrasında ilk olarak, 20.05.2021 tarihinde son güncellemesi yapılan 196 numaralı genelge $\mathrm{e}^{39}, 30.06 .2021$ tarihinde son güncellemesi yap1lan 197 numaralı genelge ${ }^{40}$ ve 28.01.2021 tarihinde son güncellemesi yapılan 197a numaralı genelge ${ }^{41}$ ile gümrüksüz satış mağazalarına ilişkin yeni uygulamalar kamuoyuna duyurulmuştur.

Birleşik Krallık hukukunda gümrüksüz satış mağazaları export shop olarak adlandırılmaktadır. Lisans başvuruları Birleşik Krallık Gelir ve Gümrük İdaresi'ne (HMRC) ${ }^{42}$, çevrimiçi bir başvuru formunun doldurulması suretiyle yapılmaktadır. Birleşik Krallık hukukunda export shop, tüketim antreposu olarak ifade edebileceğimiz excise warehouse sınıfında kabul edilmektedir (Notice 197a/3). Birleşik Krallık'ta export shop lisansı için gerçek kişi işletmeleri (sole proprietor), ortaklıklar (partnerships) ve anonim şirketler (corporate bodies) başvuruda bulunma imkânına sahiptir (Notice 196/3.1). Bununla birlikte HMRC kapsamlı bir araştırma ve değerlendirmede bulunacak ve özellikle de ticari anlamda bu işin başvuru sahibi tarafindan yürütülemeyeceği kanısına varırsa, başvuruyu reddedecektir ${ }^{43}$. Burada önem taşıyan bir diğer husus da işletme ya da şirketlerin tür değiştirmesi, şahıs işletmesinin ortaklığa dönüşmesi ya da antreponun lisans sahibi olmayan bir şirket tarafından devralınması gibi durumlarda önceki lisansın hükmünü yitirecek olması ve yeniden başvuru yapmak gerektiğidir ${ }^{44}$. Benzer şekilde lisans sahibinin işletmeyi satması ya da devretmesi halinde de devralanın yeni bir başvuru yapması gerekmektedir (Notice 196/4.11). Bir diğer

39 Excise Notice 196: excise goods - registration and approval of warehousekeepers, warehouse premises, owners of goods and registered consignors - GOV.UK (www.gov.uk) (Erişim Tarihi: 30.06.2021).

40 Receive goods into and remove goods from an excise warehouse (Excise Notice 197) GOV.UK (www.gov.uk) (Erişim Tarihi: 30.06.2021).

41 Excise Notice 197a: excise goods - holding and movement - GOV.UK (www.gov.uk) (Erişim Tarihi: 30.06 .2021 ).

42 Her Majesty's Revenue and Customs.

$43 \mathrm{Bu}$ araştırma yapılırken başvuru sahiplerinin, şirket ortaklarının mali yapısı, geçmişi, daha önce ceza alıp almadıkları gibi hususlar irdelenecektir. Hemen belirtelim ki, burada İngiliz otoriteleri araştırma yapılacak kişileri tek tek belirlemekten ziyade "key persons" kavramı üzerinden yola çıkmış ve işletme ya da şirket üzerinde etkili anahtar rolüne sahip kişilerin tespit edilerek araştırılacağının altı çizilmiştir (Notice 196/3.2).

44 Kilit role sahip kişilerdeki değişikliklerde ise HMRC, yeniden değerlendirme hakkını saklı tutmaktadır (Notice 196/3.4). 
önemli durum da lisans onayının süre bakımından iki safhalı olmasıdır. Gerçekten de alınan lisans ilk etapta 12 aylık olacak, bu sürenin sonunda yapılacak yeniden değerlendirme neticesinde sürenin uzatılması mümkün olabilecektir (Notice 196/4.7).

\section{Karşılaştırmalı Hukuk Açısından Ulaşılan Sonuçlar}

Yukarıda yaptığımız karşılaştırmalı hukuk araştırması bize göstermektedir ki, gümrüksüz satış mağazalarına ve bu mağazaların kurulup işletilmesine ilişkin esaslara hemen bütün ülkelerde büyük önem atfedilmiş ve ayrıntılı birtakım düzenlemelere konu edilmiştir. Yine bu araştırma neticesinde gümrüksüz satış mağazalarının antrepo vasfına sahip olduğu, yapılan düzenlemelerin de antrepo vasfi ekseninde gerçekleştirildiği görülmektedir. $\mathrm{Bu}$ durum gayet normaldir; zira depolama olgusu bu mağazaların doğasından kaynaklanan bir zaruret olarak karşımıza çıkmaktadır. Bir diğer önemli husus da mağaza kurucularında aranan şartlar konusunda farklı ülkelerin büyük oranda benzer düzenlemeler içermekle beraber, bazı ülkelerde gerçek kişilere mağaza açma imkânının tanınmamış olmasıdır. Mağaza açma izninin çeşitli sürelerle sınırlandırılması, mağaza kurucularında birtakım iktisadi ve hukuki şartlar aranması ve bu konuda araştırma yapılması ayrıca mağazaların devredilmesi halinde devre bazı önemli sonuçlar öngörülmüş olması da burada ayrıca zikredilmelidir.

\section{TÜRK HUKUKUNDA GÜMRÜKSÜZ SATIŞ MAĞAZA- LARINA İLISSKINN DÜZENLEMELER}

\section{A. Genel Olarak}

Gümrüksüz satış mağazaları ülkemizde kanuni anlamda ilk olarak halen de yürürlükte bulunan 27.10.1999 tarihli ve 4458 sayılı Gümrük Kanunu (GK) ile düzenlenmiştir ${ }^{45}$. Ancak 4458 sayılı Gümrük Kanunu'nun ilk halinde gümrüksüz satış mağazaları konusunda özel bir düzenleme bulunmadığını da belirtmek gerekir. Gümrük Kanunu'nun yürürlüğe girmesinden çok sonra, 2009 yılında 5911 sayılı kanunun 21. maddesi ile yapılan değişiklikle ${ }^{46}, 95$. maddenin birinci fikrası, “...gümrük kapılarında eşya satışı yapmak üzere özel antrepo statüsünde mağaza ve bunların depolarının açılması ve işletilmesine izin vermeye Müsteşarlık yetkilidir. İznin verilmesine, bu iznin geçici veya sürekli geri alınmasına, faaliyet, belge ve kayıt düzenine

45 Bu kanun 04.11.1999 Tarih ve 23866 sayılı RG'de yayımlanmış ve yayımını izleyen tarihten itibaren 3 ay sonra yürürlüğe girmiştir (GK md. 247).

$46 \quad 07.07 .2009$ tarih ve 27281 sayılı RG. 
iliş̧in usul ve esaslar ile eşya alabilecek kişiler ve bu kişilere satılabilecek eşyanın cins ve miktarı yönetmelikle belirlenir" şeklini aldı. Böylelikle gümrüksüz satış mağazaları da kanuni bir dayanağa kavuşmuş oldu. Gümrüksüz satış mağazalarının Gümrük Kanunu'nda ancak 2009 yılında yer bulabilmesinin nedenini ise, ortaya çıkmasından bu yana mağazaların uzunca bir süre genel antrepo olarak kabul edilmesi ve genel antrepolara ilişkin hükümlerin bu mağazalara da uygulanmasında aramak gerekir ${ }^{47}$.

Bununla birlikte ülkemizde gümrüksüz satış mağazalarına ilişkin olarak yürürlüğe konulan yönetmeliklerin ise eski tarihlere kadar gittiği görülmektedir.

Burada ilk olarak 1968 tarihli Gümrük Hattı Dışı Vergisiz Eşya Satış Mağazaları (Duty Free Shop) Yönetmeliği zikredilmelidirr ${ }^{48}$. Bu yönetmeliğin 2. maddesi, duty free shop'ların genel antrepolara ilişkin hükümlere tabi olduğu ve Gümrük ve Tekel Bakanlığı'nın izni olmadan devredilemeyeceğini hükme bağlanmıştır. Bu yönetmeliğin kanımca en önemli özelliği, İngilizce bir ifadeyi, "Duty Free Shop" şeklinde fiilen kullanmış olmasıdır. Bu yönetmelik daha sonra 1974 tarihli Gümrük Hattı Dışı Eşya Satış Mağazaları ve Depoları Yönetmeliği ile yürürlükten kaldırılmıştır ${ }^{49}$. Bu yönetmelik de, tıpkı öncekinde olduğu gibi, gümrüksüz satış mağazalarını genel antrepo olarak kabul etmiştir (md. 4). Söz konusu yönetmeliğin 1985 tarihli Gümrük Hattı Dışı Eşya Satış Mağazaları ve Depoları Yönetmeliği ile yürürlükten kaldırıldığı görülüyor ${ }^{50}$. Yürürlüğe giren bu yeni yönetmeliğin 3 . maddesinin $\mathrm{b}$ bendi uyarınca gümrüksüz satış mağazalarının genel antrepo niteliğinin burada da değişmediği anlaşılmaktadır. 1999 yılına gelindiğinde gümrüksüz satış mağazaları Gümrük Hattı Dışı Eşya Satış Mağazaları ve Depoları Yönetmeliği adlı yeni bir yönetmelikle tekrar düzenlenmiştir ${ }^{51}$. Bu

$47 \quad$ 01.08.1972 Tarih ve 14263 sayılı Resmî Gazete'de yayınlanarak yürürlüğe giren 1615 Say1lı Gümrük Kanunu'nun yürürlükte bulunduğu dönemde "gümrük hattı" kavramı benimsenmiş (md. 14) ve antrepolar (dolayısıyla gümrüksüz satış mağazaları) da gümrük hattı dışında sayılan yerlerden kabul edilmişti. Her ne kadar 4458 Sayılı yeni Gümrük Kanunu, 1615 sayılı kanundan farlı olarak "gümrük bölgesi” kavramı benimsenmiş ve antrepoları gümrük bölgesi içinde kabul etmiş olsa da, antrepoya konan eşyanın niteliğinde bir değişikliğe gidilmemiş ve bu eşyalar kural olarak (serbest dolaşıma girmedikçe) gümrük yükümlülüğüne tabi tutulmamıştır; bkz. Yerci, Cahit: Yorum ve Açıklamalarla Gümrük Hukuku ve Davaları, 2. Bası, Seçkin Yayınları, Ankara, 2020, s. 56.

$48 \quad 12.11 .1968$ tarih ve 13049 say1l RG.

$49 \quad 23.01 .1974$ tarih ve 1477 say1l $\mathrm{RG}$.

$50 \quad 24.08 .1985$ tarih ve 18852 say1l $\mathrm{RG}$.

$51 \quad 22.07 .1999$ tarih ve 23763 say1l $\mathrm{RG}$ 
yönetmelik de, tıpkı diğerleri gibi bu mağazaları genel antrepo olarak kabul etmektedir (md. 3/d bendi).

Ancak 1999 yılında yürürlüğe giren yönetmeliğin ömrünün çok kısa olduğunu belirtmek gerekir. Bunun nedeni de 27.10.1999 tarihli ve 4458 say1lı Gümrük Kanunu'dur. Bu kanunla birlikte yeni bir yönetmelik yayınlanmış Gümrük Hattı Dışı Eşya Satış Mağazaları ve Depoları Yönetmeliği adıyla yürürlüğe girmiş bulunmaktadır ${ }^{52}$. Bu yönetmelikle birlikte gümrüksüz satış mağazalarının artık özel antrepo olarak kabul edildiğini de belirtmek gerekir (md. 3/c bendi). 2006 yılına gelindiğinde tekrar değişikliğe gidilmiş ve yeni bir yönetmelik yürürlüğe konulmuştur. Bu yönetmelikle birlikte duty free shop'lar mevzuatta "gümrüksüz satış mağazaları" olarak anılmaya başlanmıştır. Zaten yeni yönetmeliğin de adı Gümrüksüz Satış Mağazaları Yönetmeliği' dir ${ }^{53}$. Bu yönetmeliğin $\mathrm{md}$. 3/c bendi hükmü de gümrüksüz satış mağazalarının özel antrepo niteliğinde olduğuna vurgu yapmıştır.

Nihayet 2017 yılında yürürlüğe giren ve halen de yürürlükte bulunan Gümrüksüz Satış Mağazaları Yönetmeliği (GSMY) ile konu tekrar ele alınmış ve düzenlenmiş bulunmaktadır ${ }^{54}$.

Gümrüksüz satış mağazaları konusundaki bir diğer düzenleme de Gümrük Yönetmeliği (GY) md. 552 hükmüdür. Bu maddenin birinci fikrası mülga 2006 tarihli yönetmeliğe atıf yapmakta ve "Gümrüksüz satış mağazaları ve depolarının kuruluş, işleyiş ve eşya satışına ilişkin esaslar, 13/10/2006 tarihli ve 26318 sayılı Resmî Gazete'de yayımlanan Gümrüksüz Satış Mağazaları Yönetmeliği hükümlerine tabidir" ifadelerine yer vermektedir. Kuşkusuz defalarca değişikliğe uğrayan Gümrük Yönetmeliği’nin bu hükmünün de değiştirilmesi gerekirdi. Şu durumda söz konusu yönetmelik artık yürürlükte olmadığından bu madde hükmündeki atfın 2017 tarihli yeni yönetmeliğin 38/2 hükmü gereği yeni yönetmeliğe yapılmış olduğu kabul edilmelidir.

Gümrük Yönetmeliği'nin de gümrüksüz satış mağazaları açısından kaynak vazifesi bulunmaktadır. Nitekim mezkûr yönetmeliğin md. 552/2 hükmü, "Gümrüksüz satış mağazaları ve depolarının kuruluş, işleyiş ve eşya satışına ilişkin Gümrüksüz Satış Mağazaları Yönetmeliğì'nde hüküm bulunmayan hallerde bu Yönetmelik hükümleri uygulanır" diyerek bu duruma işaret etmiş bulunmaktadır.

10.03.2000 tarih ve 23989 say1l RG.

13.10.2006 tarih ve 26318 say1lı RG.

08.08.2017 tarih ve 30148 say1l RG. 


\section{B. Gümrüksüz Satış Mağazalarının Tanımı ve Türleri}

GSMY md. 3/1-f bendi hükmünde gümrüksüz satış mağazası "1 inci maddede belirtilen kişilere satış yapmak üzere açılmasına ve işletilmesine izin verilen ve özel antrepo sayılan yerler" şeklinde tanımlanmaktadır. Yönetmeliğin birinci maddesindeki kişileri de içerecek şekilde yapılacak tanıma göre gümrüksüz satış mağazalarının, Türkiye'ye gelen veya Türkiye'den giden yolcular ile transit yolculara, diplomatik muafiyetten yararlananlara, yabancı basın yayın organlarının yabancı uyruklu mensuplarına, İstanbul Boğazı ve Çanakkale Boğazı'ndan transit geçen gemilere ve Gümrük ve Ticaret Bakanlığınca belirlenecek diğer kişilere satış yapmak üzere açılmasına ve işletilmesine izin verilen ve özel antrepo sayılan yerler" şeklinde tanımlanması mümkündür.

Gümrüksüz Satış Mağazaları Yönetmeliği'ne göre gümrüksüz satış mağazalarının, gemilere satış mağazası (shipstore), uçakta satış mağazası ve klasik anlamda gümrüksüz satış mağazası olmak üzere üç farklı türünün bulunduğu görülmektedir ${ }^{55}$.

\section{Gümrüksüz Satış Mağazası Açma ve İşletme İzni Verilmesi, Mağazanın Faaliyete Geçmesi}

Gümrüksüz satış mağazalarının kurulması ile faaliyete geçmelerini birbirinden ayırt etmek gerekir. Yönetmelik mağaza kurulmasını mağaza açma olarak ifade etmiş ve mağaza açma izni için başvuruda bulunabilecekleri sınırlandırmıştır. Buna göre mağaza açma başvurusu kamu kurumları ile asgari beş yıldır faaliyette bulunan ${ }^{56}$, ödenmiş sermayeleri ve ihtiyatları toplamı en az 1.000.000 (bir milyon) TL ve son beş yılda tahakkuk eden kurumlar vergisinin basit ortalamas1 en az 50.000 (elli bin) TL olan limited

55 Gemilere satış mağazası İstanbul Boğazı ve Çanakkale Boğazı'ndan transit geçen gemiler ile yurtdışına sefer yapmak üzere mağazanın bulunduğu limandan hareket eden yerli ve yabancı gemilere kumanya olarak satış yapmak üzere açılan ve özel antrepo sayılan yerleri (GSMY md. 3/1-d); uçakta satış mağazası ise yolculara uçak içinde satılmak amacıyla sadece yabancı ülkelere sefer yapan uçaklara eşya teslimi yapmak üzere hava hudut kapılarında yolculardan arındırılmış yerlerde açılan ve özel antrepo sayılan yerleri (GSMY md. 3/1-1) ifade etmektedir.

56 Danıştay 6. D, 12.02.1998 T., E. 1997/1300, K. 1998/769: "Davacı şirketin, gümrük hattı dış1 eşya satış mağazaları ve depoları yönetmeliğinin 5. maddesi hükmü olan anonim şirketlere asgari beş yıldan beri faaliyetlerini sürdürüyor olmaları şartıyla, mağaza ve depo açma izni verilebileceği koşulunu taşımaması nedeniyle ihalelere girmesinde sakınca olmadığı konusunda belge verilmemesinde hukuki isabetsizlik bulunmadığı..." (www.legalbank.net) (Erişim Tarihi: 07.09.2021) 
veya anonim şirketler tarafından yapılabilecektir (GSMY md. 6/1) ${ }^{57}$. Böylelikle yönetmeliğin gerçek kişilerin gümrüksüz satış mağazası açmasına müsaade etmediği görülüyor ${ }^{58}$. Acaba mağaza açma başvurusunda bulunabilecek anonim şirketlerin paylarının hamiline yazılı olması mümkün müdür? Yönetmelik hükümleri irdelendiğinde bu konuda bir sınırlandırmaya gidilmediği görülmektedir. Hatta GSMY md. 6/3 hükmü, şirket sermayesinin yüzde onundan fazlasına sahip gerçek kişiler bakımından belli bazı suçlardan kesinleşmiş ceza ve mahkûmiyet kararının bulunmamasını şart kılmış olmasına rağmen, yönetmelik payların hamiline ya da nama yazılı olması ile ilgili bir hükme yer vermemiştir. Şu durumda mağaza açma başvurusundan bulunabilecek anonim şirketlerde paylar hamiline yazılı olabilecektir.

Gerekli şartları taşıyanların ilk aşamada ön izin almak için başvuruda bulunmaları gerekmektedir. Yönetmeliğin 7. maddesi ön izin başvurusu için başvuru dilekçesine eklenecek belgeler arasında mağaza veya depo olarak açılmak istenilen yeri gösteren resmî plan veya kroki, söz konusu yerin mülkiyetinin veya üzerindeki sınırlı aynî hakkın başvuru sahibine ait olduğunu belgeleyen tapu sicil örneği veya kira sözleşmesini de saymıştır. Dolayısıyla henüz ön izin alınmadan, işyeri kira sözleşmesinin akdedilmesi gerekecektir. Ayrıca belirtelim ki, yönetmeliğe göre ön izin başvurusunun uygun bulunması, mağaza veya depoya aç1lış izni verileceği anlamına da gelmeyecektir (GSMY md. 7/1, son cümle).

57 Ayrıca yönetmelik başvuruda bulunacak tüzel kişilerin yönetim kurulu üyeleri, sermayesinin yüzde onundan fazlasına sahip gerçek kişiler ile limited şirketlerde ortaklar ile şirket müdürünün belli bazı suçlardan kesinleşmiş ceza ve mahkûmiyet kararı bulunmamasını gerekli görmektedir (GSMY md. 6/3). Keza başvuru sahibi limited ve anonim şirketlerin gümrük mevzuatı uyarınca kesinleşmiş vergi ve ceza borcu ile vergi mevzuatı uyarınca kesinleşmiş vergi borcu bulunmaması da başvuru şartları arasında yer almaktadir (GSMY md. 6/4).

58 Kanaatimizce GSMY'nin gerçek kişilerin gümrüksüz satış mağazası ve depo açmasına imkân tanımayan bu hükmü Gümrük Kanunu'na ve aynı zamanda 1982 Anayasası bağlamında eşitlik (md. 10) ve girişim özgürlüğü (md. 48) ilkelerine aykırı niteliktedir. Her şeyden önce kanunun 95. maddesine göre bu mağaza ve depolar özel antrepo niteliğindedir. Bu konudaki tek sınırlama üçüncü fikrada yer alan iznin yalnızca Türkiye'de yerleşik kişilere verilebileceğine ilişkin md. 95/3 hükmüdür. Keza 95. maddenin birinci fikrasının ikinci cümlesi de "İznin verilmesine, bu iznin geçici veya sürekli geri alınmasına, faaliyet, belge ve kayıt düzenine ilişkin usul ve esaslar ile eşya alabilecek kişiler ve bu kişilere satılabilecek eşyanın cins ve miktarı yönetmelikle belirlenir" diyerek yönetmelikle düzenlenebilecek hususları belirtmiştir. Nitekim (GSMY'den farklı olarak) Gümrük Yönetmeliği'nin 518. maddesi, gerçek kişilerin antrepo açmak için başvurabileceğini hükme bağlamıştır. 
Ön izin aşamasından sonra ise mağaza ve depo açma izni için yönetmeliğin 7. maddesinin 2. fikrasındaki ${ }^{59}$ belgelerle birlikte gümrük müdürlüğüne müracaat edilmesi gerekmektedir. Burada yönetmeliğin $7 / 2$ hükmü $c$ bendi uyarınca kira sözleşmesinin de aranan belgeler arasında bulunduğunu tekrar belirtmekte fayda görmekteyim. Böylelikle mağazanın açılması için henüz izin alınmadan, kiraya veren ile kira sözleşmesinin yapılmasının başvuru için ön şart olarak kabul edildiği anlaşılmaktadır. Gerek ön izin aşamasında ve gerekse ön iznin alınmasını müteakip müracaat aşamasında ibraz edilmesi gereken kira sözleşmesinin; ön iznin alınamaması, alınsa da sonradan geri alınması ya da mağaza açma iznine yönelik müracaatın kabul edilmemesi durumunda, akıbetinin ne olacağı oldukça önem taşıyan bir konu olup Yargıtay'ın birbirinden farklı kararları mevcuttur ${ }^{60}$. Bu tip hallerde şarta bağlı bir kira sözleşmesinin akdedilmesi mümkündür. Uygulamada mağaza açma başvuruları çoğunlukla ihale usulü ile yapıldığından, başvuru aşamasında ilgili kamu kurumu ile şarta bağlı bir kira sözleşmesi akdedilmesi de imkân dâhilindedir.

59 Gemilere satış mağazası açmak için ayrıca 3.fikradaki belgeler

60 Yargitay 11. HD, 31.03.2005 T., E. 2004/4949, K. 2005/3078: "Davac1 vekili, müvekkilince davalıdan kiralanan gümrük hattı dışı eşya satış mağazasının Gümrük Müsteşarlığı'nca izin verilmemesi nedeniyle işletilememesine karşın davalıya kira parasının ödene geldiğini ileri sürerek, başlangıcından itibaren kira sözleşmesinin feshini ve ödemelerin istirdadını talep ve dava etmiştir... Mahkemece, asıl davanın açılmamış sayılma koşullarının oluştuğu, Eylül-2001 ayı kira parası ve eklentilerinin davacı kiralayan tarafından istenebileceği gerekçesiyle...karar verilmiştir. Hükmün onanmasına.." (www.legalbank.net) (Erişim Tarihi: 07.09.2021); Yargıtay 11. HD, 27.04.2006 T., E. 2005/3923, K. 2006/4789: "Davacı vekili, müvekkili şirketin 24.09.2001 tarihli kira sözleşmesi ile mülkiyeti ve tasarrufu davalıya ait, kullanım şekli free shop olan büroyu Amerikan Doları karşılığı kiraladığını, ancak aradan oniki aya yakın bir zaman geçmesine rağmen ruhsat verilemediği için müvekkilinin kiralananı işletmeye açamadığını, buna karşı1lı sekiz aylık kirasını düzenli olarak ödediğini ve ABD doları karşılığı teminat yatırdığını, davalının ruhsat verilemeyecek bir yeri kiraya vermek suretiyle müvekkili şirketin zararına sebebiyet verdiğini ileri sürerek ödenen kira bedeli ve teminat olarak yatırılan tutarın davalıdan tahsilini talep ve dava etmiştir. Davalı vekili, gümrük hattı dışı eşya satış mağazası yeri olarak inşa edilen altı adet mağaza yerinin açılması için gerekli iznin alınması üzerine ihale yapıldığını, ihale sonucu davacı ile düzenlenen kira sözleşmesinin 11. maddesinde, tesisin işletmeye açılabilmesi için gerekli olan tüm ruhsat ve izinlerin kiracı tarafından ilgili merciden alınacağının kararlaştırıldığını, ruhsat, izin ve müsaadeleri alamamak veya geç almanın kira bedelinin ödenmesini engellemeyeceğini, bu nedenlerle davanın reddini istemiştir. Mahkemece, taraflar arasında imzalanan sözleşmede davacının ileri sürdüğü hususların çözümünün kendisine bırakıldığı gerekçesiyle davanın reddine karar verilmiştir...Kira bedelleri yönünden hükmün onanmasına, sözleşmede belirtilen teminatın iadesi şartlarının oluşup oluşmadığının araştırılmaması nedeniyle bu yönden bozulmasına..." (www.legalbank.net) (Erişim Tarihi: 07.09.2021) 
Müracaat aşamasında talep edilen belgelerden bir diğeri de yönetmelik md. 7/2-a bendinde yer alan yönetim kurulu üyeleri, şirket sermayesinin $\% 10$ veya daha fazlasına sahip gerçek kişiler ile limited şirketlerde ortaklar ile şirket müdürünün, başvuru tarihinden geriye dönük en geç iki ay içinde alınmış adlî sicil belgeleridir. Ayrıca bu belgenin her yıl düzenli olarak ilgili gümrük müdürlüğüne ibrazı da gerekmektedir (GSMY md. 9/1). Elbette bu kişilerin adli sicillerinin "temiz" olmasının aranması ve yönetmelik md. 6/3 hükmünde belirtilen suçlardan mahkûmiyet bulunup bulunmadığının tespiti açısından bu belge önemlidir. Ancak yönetmelik md. $7 / 5^{\prime}$ de ise şöyle bir düzenleme yer almaktadır:

"Mağaza veya depo açma izni almak üzere başvuracak tüzel kişilerin yönetim kurulu üyeleri ve şirket sermayesinin \%10 undan fazlasına sahip ortaklar arasından yurt dışında ikamet eden yabancı şahısların, yurt dışında ikamet ettiklerine dair ilgili makamlardan alınan resmi bir belge ibraz etmeleri halinde adlî sicil belgesi aranmaksızın bu kişilerin yazılı beyanlarına itibar edilir."

Görüldüğü gibi gümrüksüz satış mağazası açmak açısından aranan en önemli şartlardan birisine, yurt dışında ikamet eden yabancı şahıslar bakımından çok önemli bir istisna getirilmiş bulunmaktadır. Bir başka ifadeyle yönetmelik, Türk vatandaşlarının sözünü resmi bir adli sicil kaydıyla belgelemesini gerekli kılarken, yurt dışında ikamet eden yabancı şahısların sözüne itimat etmektedir. Oysa yabancı ülkelerden alınmış adli sicil belgesi hükmündeki belgelerin noter çevirili örneklerinin talep edilebilmesi gerekirdi. Sonuç olarak bu düzenlemenin girişimci Türk vatandaşları aleyhine olduğu ve eşitlik ilkesine aykırılık teşkil ettiği görülmektedir.

Başvurunun uygun bulunması durumunda gümrük müdürlüğünün yazı11 ve gereken harçların ödenmesine müteakip, başvuru sahibine mağaza açma ve işletme izni verilecektir (GSMY md. 7/7). Yönetmeliğe göre gümrüksüz satış mağazası ve deposu açma ve işletme izinleri, açma ve işletme izin belgesinin düzenlendiği tarihten itibaren beş yıl geçerli olacak şekilde verilebilmektedir (GSMY md. 7/9). Bu sürenin, iznin sona ermesinden en erken dört ay ve en geç bir ay önce talep üzerine uzatılması mümkündür. Bununla birlikte yönetmelik md. 7/9'un son cümlesi bu beş y1llık süreyi önemli ölçüde işlevsiz hale getirmektedir. Gerçekten de bu son cümleye göre gümrüksüz satış mağazası işleteni ile hudut kapısı işleteni arasındaki kira 
akdinin 5 yıldan uzun olması halinde kira sözleşmesinin süresi, izin belgesinin geçerliliği açısından dikkate alınacaktır ${ }^{61}$.

Mağaza açma ve işletme izni verilmesinden sonra izin yazısının tebliğ tarihini izleyen günden itibaren altı ay içinde mağazanın faaliyete geçmemesi durumunda verilen izin iptal edilecektir (GSMY md. 8/2). Faaliyete geçebilmek için aranan şartların başında ise yönetmelik hükümlerine uygun bir teminat verilmesi şartı özellikle zikredilmelidir (GSMY md. 8/1).

\section{Gümrüksüz Satış Mağazalarının Belli Başlı Özellikleri}

\section{Hukuki Niteliği}

\section{a. Gümrüksüz Satış Mağazalarının Özel Antrepo ve Ticari İşletme Niteliği}

Gümrük Kanunu ve Gümrüksüz Satış Mağazaları Yönetmeliği'ne göre gümrüksüz satış mağazaları hukuki anlamda özel antrepo niteliğindedir ${ }^{62}$.

61 Bu hüküm yönetmeliğe 14.02.2018 tarihli ve 30332 sayılı RG’de yayınlanan değişiklik ile ilave edilmiştir.

62 Gümrük Kanunu md. 93/3 hükmüne göre gümrük antreposu, gümrük gözetimi altında bulunan eşyanın konulması amacıyla kurulan ve kuruluşunda aranılacak koşulları ve nitelikleri yönetmelikle belirlenen yerdir. Doktrinde ise antrepo ile ilgili daha geniş tanımlamalar görmekteyiz. Örneğin Yerci antrepoyu, "ithalat vergilerine ve ticaret politikası önlemlerine tabi tutulmamış ve serbest dolaşıma girmemiş eşya ile serbest dolaşımda bulunan eşyanın konulabildiği yer" olarak tanımlamaktadır; bkz. Yerci, s. 56. Türk Hukuk Lügati antrepoyu "Gümrük ve gümrük idaresi delâletiyle tahsil edilen vergi ve resimleri ödenmemiş olan malların muhafazası için kurulan depo" şeklinde ifade etmiştir; bkz. Türk Hukuk Lügati, Türk Hukuk Kurumu, 3. Bası, Türk Hukuk KurumuBaşbakanlık Mevzuatı Geliştirme ve Yayın Genel Müdürlügü̈, Başbakanlık Basımevi, Ankara 1991, s. 18. Y1lmaz'1n ise genel anlamda antrepoyu "ticari malların korunması için kullanılan depo, ardiye, anbar, ambar", gümrük antreposunu ise "Türkiye'ye girmesi veya Türkiye'den transit geçirilmesi yasak olmayan yabancı memleket eşyasının, çıkış hükmünde olmak üzere ihraç edilecek milli mahsul ve mamullerin, transit veya yeniden ihraç edilmek üzere gelen eşyanın, konulduğu yer" ifadeleriyle altladığı görülüyor; bkz. Yılmaz, Ejder: Hukuk Sözlügüu, 5. Bası, Yetkin Yayınları, Ankara, 1996, s. 65-66. GK md. 94 hükmü antrepoları eşyanın konulması için herkes tarafından kullanılabilen genel antrepolar ve yalnız antrepo işleticisine ait eşyanın konulabildiği özel antrepolar şeklinde ikili bir tasnife tabi tutmuştur. GY md. 329 hükmü ise antrepo tiplerini belirlemiş ve genel antrepoların A, B ve F; özel antrepoların da C, D ve E tipinde kurulabileceğini hükme bağlamıştır. Gümrük antrepo rejimi ve antrepo tipleri ile ilgili ayrıntılı bilgi için bkz. Selen, Ufuk: Gümrük İşlemleri ve Vergilendirilmesi, 9. Bası, Ekin Yayınları, Bursa, 2017, s. 109-115; Dölek, Ali: Gümrük İşlemleri, 1. Bası, Umut Kitap Basım Yayım Dağıtım, İstanbul, 2013, s. 195-205; Canıtez, Murat: Uygulamalı Gümrük Mevzuatı, 1. Bas1, Gazi Kitabevi Yayınları, Ankara, 2017, s. 179-187; Yeşilova, Alper: Gümrük Hukukuna İlişkin Uyuşmazlıklar ve Hukuki Çözüm Yolları, 1. 
Aynı husus depolar için de geçerlidir (GK md. 95/1; GSMY md. 3/1-ç). Yine mağaza ile işletmenin muhtelif yerlerdeki mağazalarının stok ihtiyaçlarının sağlanması amacıyla eşya konulan depolar arasında sıkı bir bağ bulunduğu hatta her ikisinin bir bütün teşkil ettiği görülmektedir. Hemen belirtelim ki, ilgili alanda yer alan her mağaza değil, sadece gerekli izinler doğrultusunda ve belirlenmiş ürünlerin satışını gerçekleştiren mağazalar özel antrepo niteliğinde gümrüksüz satış mağazası statüsüne sahiptir ${ }^{63}$.

Gümrüksüz satış mağazalarının özel antrepo niteliği ${ }^{64}$ ve mağaza ile deponun bütünlüğü karşısında ${ }^{65}$, bu mağazaların TTK anlamında hukuki niteliğinin tespit edilmesi ayrıca önem taşımaktadır.

GSMY md. 6/1-b hükmü uyarınca gerçek kişilerin gümrüksüz satış mağaza ve depolarının işleteni olması mümkün değildir. Bu mağaza ve depoların sadece kamu kuruluşları ile anonim ve limited şirketler tarafından işletilmesi mümkündür. Kanımca burada meselenin gümrüksüz satış mağazasının gerçek kişiler tarafından işletilmesi ile anonim ve limited şirketler tarafından işletilmesi ihtimallerine göre ayrı ayrı ele alınması gerekmektedir. Zira her ne kadar GSMY hükümlerine göre, gerçek kişilerin gümrüksüz satış mağazası işletmesi hukuken mümkün olmasa da yönetmelik hükümlerinde

Bas1, Seçkin Yayınları, Ankara, 2017, s. 123-127; Ercan, Tayfun: Gümrük Hukuku, 1. Bas1, Ekin Yayınları, Bursa, 2019, s. 54 vd.

63 Danıştay 9. D, 17.06.2010 T., E. 2009/7111, K. 2010/3174: "Davacı şirketin havaalanı dış hatlar terminali yolcu çıkış salonunda pasaport kontrol noktasından sonra, yolcular tarafından uçak hareket saatinin beklendiği alanda sunduğu hizmetin, uçağın seyrüseferine ve yolcuların yükleme-boşaltma faaliyetlerine ilişkin, sadece uçağın hareket saatini bekleyen yolculara, bedellerini kendilerinin ödediği isteğe bağlı hızlı bir yeme içme hizmeti olduğu görüldüğünden davacı şirket tarafından işletilen kafenin ilgili yönetmelikte aranan izin ve tutulması gerekli defter ve belge şartlarına sahip olmadığı halde özel antrepo kapsamında değerlendirilmesinde isabet bulunmadığı.." (www.legalbank.net) (Erişim Tarihi: 07.09.2021)

64 Hemen belirtelim ki, gerek GK ve gerekse GSMY gümrüksüz satış mağaza ve depolarının hangi tip özel antrepo olduğuna ilişkin bir hükme yer vermemiştir. Ancak özel antrepo tipleri arasında yer alan C tipi antrepoya ilişkin GY md. 329/1-c hükmünde yer alan, "işleticisi ve kullanıcısı aynı kişi olan ve antrepoya alınan eşyadan bu kişinin sorumlu olduğu özel antrepo tipidir" şeklindeki tanım karşısında gümrüksüz satış mağaza ve depolarının $\mathrm{C}$ tipi antrepo niteliğine sahip olduğu söylenebilecektir. $\mathrm{C}$ tipi antrepolarda özellikle de sipariş üzerine çalışan işletmelerin, gelen talebe göre eşyayı antrepo rejimine tabi tutabildiği konusunda ayrıca bkz. Tekin, Abdulkadir/Tekin, Ümit Engin: 4458 Sayılı Gümrük Kanunu'na Göre Gümrük İşlemleri, 2. Bası, Seçkin Yayınları, Ankara, 2018, s. 149 vd.

65 Uygulamada mallar evvela depolara gelmekte daha sonra mağazalara satış için intikal ettirilmektedir. Bu nedenle her mağazaya ait bir depo bulunması fiili bir gereklilikten kaynaklanmaktadır; bkz. Kaliç, s. 4. 
değişikliğe gidilerek buna imkân tanınması her zaman için ihtimal dahilindedir.

Yönetmelik hükümlerinde değişikliğe gidilerek gerçek kişilerin de gümrüksüz satış mağazası işletmesine imkân tanınması ihtimali, meselenin TTK md. 11 bakımından irdelenmesini gerektirmektedir. TTK md. 11 uyarınca bir işletmenin ticari işletme olarak telakki edilebilmesi için esnaf işletmesi için öngörülen sınırı aşan düzeyde gelir sağlamayı hedeflemesi, faaliyetlerin devamlı ve bağımsız şekilde yürütülmesi şartır. Dolayısıyla GSMY'nin gerçek kişilere de gümrüksüz satış mağazası açma ve işletme izni tanıması durumunda; TTK md. 11 hükmündeki şartları taşımak kaydıyla, gerçek kişiler tarafından işletilen bir gümrüksüz satış mağazasının ticari işletme olarak kabul edilmesi mümkündür.

Gümrüksüz satış mağazalarının anonim ve limited şirketler tarafından işletilmesi durumunda ortaya daha farklı bir sonuç çıkacaktır. Şöyle ki, anonim ve limited şirketlerin zorunlu olmamakla beraber ticari işletme işletmesi her zaman için imkân dahilindedir. Böyle bir durumda TTK md. 16 hükmü doğrultusunda, salt işleteni bir ticaret şirketi olması nedeniyle, gümrüksüz satış mağazası da ticari işletme hüviyetine bürünecektir. Başka bir söyleyişle işletenin bir anonim veya limited şirket olması durumunda, TTK md. 16 uyarınca gümrüksüz satış mağazası ticari işletme olarak kabul edilecektir. Uygulamada gümrüksüz satış mağazacılığı yapan şirketlerin ana sözleşmeleri üzerinde yaptığımız araştırmada, bu şirketlerin birbirinden farklı iştigal sahalarının da bulunabildiği ve gümrüksüz satış mağazacılığının da bu iştigal sahalarından birini teşkil ettiği görülmüştür. Örneğin bir şirketin gümrüksüz satış mağazacılığının yanı sıra marina yatırım ve işletmeciliği, konaklama hizmetleri yapması da mümkündür. Böyle bir durum ise, her iki faaliyet kolunun ayrı bir ticari işletme olarak kabul edilmesini gerektirecektir. Keza anonim ve limited şirketin münhasıran gümrüksüz satış mağazası işletmek amacıyla kurulduğu hallerde de sonuç değişmeyecek ve mağaza yine ticari işletme hüviyetine bürünebilecektir.

\section{b. Birden Fazla Gümrüksü̈z Satış Mağazası İşletilmesi Halinde Mağazaların Hukuki Niteliği}

Bir anonim ya da limited şirketin birden fazla gümrüksüz satış mağazası işletmesi mümkündür. Böyle bir durumda karşımıza temel olarak iki ihtimal çıkmaktadır. Bu konudaki ilk ihtimal her bir gümrüksüz satış mağazasının münhasır bir ticari işletme olarak kabul edilmesidir. Zira mağazaların ayrı bir ticari işletme olarak telakki edilmeleri her zaman için imkân dahilindedir. Örneğin farklı sınır kapılarındaki gümrüksüz satış mağazalarının, 
aynı anonim ya da limited şirket tarafından birbirinden bağımsız şekilde işletilmesi mümkündür. Bu takdirde her iki mağaza da ayrı ayrı ticari işletme niteliğinde olacaktır.

İkinci ihtimal ise bir anonim ya da limited şirketin işlettiği birden fazla gümrüksüz satış mağazasının merkez ve şube ilişkisinin varlığı bakımından irdelenmesini gerektirmektedir. Ancak birden fazla gümrüksüz satış mağazasının varlığg halinde, ticaret şirketi bünyesinde merkez-şube ilişkisinin nas1l tesis edileceği büyük önem taşımaktadır. Her şeyden önce ticaret şirketleri bünyesinde bir şubenin varlığından söz edebilmek için, ortada bir ticari işletmenin bulunması gerekir ${ }^{66}$. Bir başka ifadeyle ticaret ortaklıklarının ticari işletme işletmesi, şubeye sahip olmasının ön şartıdır. Ayrıca merkez ve şube arasındaki farklılığın tespiti noktasında en önemli ayrımın, ticari işletmenin bünyesinde barındırdığı bağımsızlık unsuru olduğu görülmektedir ${ }^{67}$. Bağımsızlık unsuru ticari işletmenin iç ilişkide münhasıran kendisini işletenin iradesine tabi olması olarak ifade edilebilir ${ }^{68}$. Ticari işletmenin iç ilişkide alınan kararlarda sadece kendisini işletene bağlı olması aynı zamanda ticari işletmenin tacirinden bağımsız düşünülememesinin doğal bir sonucudur.

Burada açıklığa kavuşturulması gereken bir diğer husus da "satış mağazası" kavramının, gümrüksüz satış mağazaları bakımından ne anlama geldiğidir. Şube ile ilgili olarak Ticaret Sicili Yönetmeliği md. 118/1 hükmü ve 5174 sayılı Türkiye Odalar ve Borsalar Birliği ile Odalar ve Borsalar Kanunu md. 9/2 hükmünde yer alan tanımlara baktığımızda, satış mağazalarının şube olarak kabul edilmesi gerektiği yönünde bir karinenin mevcut olduğu

66 Kayış, Ferhat: Ticari İşletmede Şube Kavramı ve Şube Olmaya Bağlanan Hüküm ve Sonuçlar, 1. Bası, On İki Levha Yayıncılık, İstanbul, 2019, s. 159; Kendigelen, Abuzer (Ülgen, Hüseyin/Helvacı, Mehmet/Kaya, Arslan/Nomer Ertan, Füsun): Ticari İşletme Hukuku, 4. Bası, On İki Levha Yayıncılık, İstanbul, 2015, s. 169.

67 Bağımsızlık unsuru ticari işletme ile şubeyi ayırt etme noktasında en önemli kıstaslardan birini teşkil etmektedir. Bu anlamda faaliyetlerin başka bir işletmeye bağlı olmadan sürdürülebiliyor olunması bağımsızlık unsurunun varlığına delalettir; bkz. Şener, Oruç Hami: Ticari İşletme Hukuku, 2. Bası, Seçkin Yayınları, Ankara, 2020, s. 5; Arkan, Sabih: Ticari İşletme Hukuku, 24. Bası, Banka ve Ticaret Hukuku Araştırma Enstitüsü Yayınları, Ankara, 2018, s. 31; Nomer Ertan, Füsun (Ülgen, Hüseyin/Helvacı, Mehmet /Kaya, Arslan): Ticari İşletme Hukuku, 6. Bası, Vedat Kitapçılık, İstanbul, 2019, s. 157. $\mathrm{Bu}$ unsuru sadece işletmenin değil, işletme sahibinin de bünyesinde barındırması gerektiği yönünde bkz. Ayhan, Rıza/Çağlar, Hayrettin/Özdamar, Mehmet: Ticari İşletme Hukuku, 12. Bası, Yetkin Yayınları, Ankara, 2019, s. 105. Bağımsızlık unsurunun varlığının tespiti bakımından faaliyet düzeninin ve işletme politikasının münhasıran belirlenebilmesi, kararların tek başına alınabilmesi gibi kıstaslardan yola çıkarak bir sonuca ulaşılması mümkündür; bkz. Kayış, s. 29.

68 Kendigelen (Ülgen/Helvac1/Kaya/Nomer Ertan), s. 151. 
görülmektedir ${ }^{69}$. Bununla birlikte satış mağazalarının şube niteliğine sahip olup olmadığ 1 noktasında mezkûr düzenlemelerin öncesinde ve sonrasında doktrinde birtakım tartışmalar bulunduğunu da belirtmek gerekir ${ }^{70}$. Sözgelimi Hirş meseleye ticaretgâh kavramı ekseninde yaklaşarak olumsuz cevap verirken $^{71}$, Karayalçın ve Göle ise satış mağazalarının merkezin yürüttüğü faaliyetlerle özdeş işleri tek başına yapamaması ve salt satış işleminin de, oldukça sınırlı bir yetki ihtiva etmesi nedeniyle şube niteliğinde olmadığını savunmuşlardır $^{72}$. Buna karşıllk Pekdinçer, Kendigelen ve Özdamar satış mağazalarının şube niteliğine vurgu yapmış ${ }^{73}$, Arkan ise, şubenin merkezin

69 Satış mağazalarının şube vasfının bir karine olarak öngörülmesi doktrinde çeşitli eleştirilere konu olmuştur. Şener'e göre satış mağazaları ancak şube olabilmenin diğer şartlarını taşıması kaydı ile şube olarak kabul edilmelidir. Örneğin münhasıran satış işlemi yapabilen ve merkezin faaliyetlerine benzer faaliyetleri gerçekleştiremeyen yerlerin şube olamaması gerekir; bkz. Şener, Oruç Hami: Ticari Temsilci ve Ticari Temsil Yetkisi, 1. Bası, Adalet Yayınevi, Ankara, 2015, s. 243; Şener (Ticari İşletme), s. 12. Arkan da satış mağazalarının münhasıran satış işlemi yapabilmesi ve merkezin yaptığı faaliyetlerle özdeş faaliyetleri yapamaması nedeniyle kanunda şube olarak düzenlenmesinin hatalı olduğu kanaatindedir; bkz. Arkan, s. 36. Benzer olarak Özdamar, Mehmet: Yargıtay Kararları Işı̆̆ında Ticari İşletmede Şube Kavramı, Ankara Barosu Dergisi, 2007/1, s. 50, dn.19.

70 Bu tartışmaların dış ilişkiler bakımından satış mağazalarının durumu ile şubelerin merkezin yaptığı işlerden hangilerini yapabildiği noktalarında odaklandığı görülmektedir.

71 Yazar, "merkez olmıyan her ticaretgâh, şubedir" şeklinde düşünmekle beraber, ticaretgâh kavramına da açıklık getirmiş ve "fabrika, imalathane, atölye, ambar, silolar ve buna benzer mahallerle gişe ve satış yerleri" hakkında bunların bulunduğu yerlerde işletmenin idaresi de bulunmadıkça, buraların ticaretgâh olamayacağı savunmuştur; bkz. Hirş, E.: Ticaret Hukuku Dersleri, 3. Bası, İsmail Akgün Matbaası Hak Kitabevi, İstanbul, 1948, s. 125.

72 Karayalçın, satış mağazalarının dış ilişkide satım ilişkisine girebilme haricinde işletmeyi bağlayıcı işlemler yapamadığını, dolayısıyla merkezin faaliyetleri ile özdeş faaliyetlerde bulunamayan bu yerlerin şube niteliğinde olmadığını savunmuştur. Yazara göre süt ve yoğurt satış mağazası sadece süt ve yoğurt satabilme yetkisine sahip olup, süt tedariki ve üretimi konularında gerekli sözleşmeleri akdetme yetkisi bulunmadığından şube olarak kabul edilemez; bkz. Karayalçın, Yaşar: Ticaret Hukuku Dersleri I. Giriş-Ticari İşletme, 2. Bası, Banka ve Ticaret Hukuku Araştırma Enstitüsü Yayınları, Ankara, 1960, s. 118. Göle de, temel olarak Karayalçın'ın düşünceleri ile aynı kanıdadır. Yazara göre satış mağazaları ancak merkezin yürüttüğü faaliyetleri ya da özdeşlerini yapabiliyor ise şube olarak kabul edilebilir. Her ne kadar satış mağazaları işletme adına ve hesabına işlem yapabilse de, mağazadaki görevlinin yetkileri, merkezi bağlayabilecek işlemlerden ziyade oldukça sınırlı bir mahiyet arz eder; bkz. Göle, Celal: Ticari İşletmenin Merkez ve Şubesinin Tayini Sorunu, Prof. Dr. Ernst E. Hirsch'in Hatırasına Armağan, Ankara, 1986, s. 200 vd.

73 Pekdinçer'e göre, sadece merkez tarafından üretilen malların satışını yapabilen yerler şube olarak kabul edilemez. Ayrıca merkezin yaptığı faaliyetler türünden faaliyetlerin ya 
faaliyetlerinin tümünü değil, sadece merkezin asli nitelik arz eden faaliyetlerini yapabilmesinin şube vasfinın kazanılması açısından yeterli olduğunu ifade etmiştir ${ }^{74}$. Meseleye farklı bir bakış açısı getiren Kayış ise, bir satış mağazasının sadece merkezde üretilen ürünlerin değil, farklı ürünlerin de satışını gerçekleştirmesi halinde artık şube olarak kabul edileceğini zira bu durumda merkezin üretimi durdursa dahi, satış mağazasının satışları durdurmayacağını savunmuştur ${ }^{75}$. Yine Kayış'a göre merkez üretimle değil satışla iştigal eden bir işletme ise, merkeze bağlı satış mağazalarının da şube olarak kabul edilmesi gerekir ${ }^{76}$.

Bütün bu tartışmalara gümrüksüz satış mağazaları açısından yaklaştı̆̆1mızda mevzuatta yer alan tanımlarda satış mağazalarının şube olarak kabul edilmiş olmasının, gümrüksüz satış mağazalarının da doğrudan doğruya şube olması sonucunu doğurmayacağını belirtmek gerekir. Zira bu mağazaların isimlerinde "satış mağazası" ifadesi bulunmakla birlikte, diğer satış mağazalarına göre farklılık arz eden önemli bazı yönleri bulunmaktadır.

Öncelikle gümrüksüz satış mağazası ticari işletme niteliğinde olup; ancak birden fazla mağazanın mevcudiyeti halinde merkez-şube ilişkisi tesis edilmek suretiyle mağazaların şube olarak kabul edilmesi mümkündür. Ayrıca şubenin, merkezin yürüttüğü faaliyetlerden en az birini yürütebiliyor olması gerekliliği, bazı durumlarda gümrüksüz satış mağazaları bakımından geçerliliğini yitirebilmektedir. Çünkü bu mağazaların yürüttüğü faaliyetlerin,

da benzerlerinin de yapılabiliyor olması gerekir. Bu noktada tacirin söz konusu yeri nasıl telakki ettiği değil, mahkemenin tespiti önem taşımaktadır. Yazara göre özellikle de gıda sektöründe faaliyet gösteren süpermarketlerin, malvarlıklarının merkeze ait olması, merkezin işletme politikasına tabi olması ve hepsinin tek bir tacire ait olması karşısında şube olarak ticaret siciline tescil ettirilmeleri gerekir; bkz. Pekdinçer, Tamer: Ticaret Sicili Açısından Merkez-Şube-Satış Mağazası Kavramları, Prof. Dr. Fahiman Tekil'in Anısına Armağan, s. 478-479. Kendigelen ise üretim faaliyetinde bulunan ticari işletmelerde, satış mağazalarının üretim faaliyetinin bulunmaması ve merkezin faaliyetlerine benzer faaliyetleri yerine getirememesi nedeniyle şube sayılmaması gerektiği şeklindeki görüşe katılmadığını; üretim ve satışın bir bütün olduğunu, bu nedenle toptan satış mağazalarının, fabrika satış mağazalarının da merkezin yürüttüğü faaliyetleri yürütmesi nedeniyle şube olarak kabul edilmesi gerektiğini ve 5174 sayılı kanun ile Ticaret Sicili Yönetmeliği md. 118/1 hükmünün bunu desteklediğini ifade etmiştir; bkz. Kendigelen (Ülgen/Helvac1/Kaya/Nomer Ertan), s. 173. Özdamar, modern ticaret anlayışının sadece üretime indirgenemeyeceği bu nedenle özü itibarıyla pazarlama faaliyeti yürüten satış mağazalarının da şube olarak kabul edilmesi gerektiği kanısındadır; bkz. Özdamar, s. 56.

74 Arkan, s. 38.

75 Kayış, s. 133.

76 Kayıș, s. 134. 
mahiyeti gereği şirket merkezinde gerçekleştirilmesi mümkün değildir. Zira gümrüksüz satış mağazasında yürütülen faaliyetler, merkezin yürüttüğü faaliyetlerden değildir. Bilakis, bu faaliyetlerin görüldüğü yer ve görülme şekli itibarıyla merkezin bulunduğu yerde yürütülmesi söz konusu olmadığ 1 gibi; tam tersi, bizzat mağazanın bulunduğu yerde gerçekleştirilmesi zorunludur. Ancak bu durum bizi şubenin bağlı olacağı merkezin, şirketin ana sözleşmesinde belirtilen yer değil de merkez olarak kabul edilen gümrüksüz satış mağazası hangisi ise o mağaza olacağ1 sonucuna götürmemelidir. Zira Türk hukukunda kanuni merkez sistemi benimsendiğinden; şirketin merkezi olarak gösterilen ve idare edildiği yer ile işletmenin faaliyetlerinin fiilen yürütüldüğü yerin farklı yerde bulunabileceği, dolayısıyla şubelerin bağlı olacağı merkezin, şirketin merkezi şeklinde anlaşılması gerektiği kabul edilmektedir $^{77}$. Anonim ve limited şirketler tarafından işletilen gümrüksüz satış mağazalarında şirket sözleşmesinde belirtilen yerin merkez olarak kabul edilmesi, tüm mağazaların şube niteliğini taşıması mümkün olamayacağından hangi mağazanın ticari işletme niteliğine bürüneceği sorusunu akla getirebilir. Çünkü yukarıda belirtildiği üzere ticaret şirketlerinde şubenin varllğı, bir ticari işletmenin varlığını gerekli kılar. Böyle bir durumda mantık gereği şirket merkezinin bulunduğu yerdeki mağazanın ya da ilk açılan mağazanın ticari işletme, diğerlerinin şube olarak kabul edilmesi doğru olacaktır. Tek bir gümrüksüz satış mağazası işleten anonim veya limited şirketler bakımından ise şirketlerin ana sözleşmede belirtilen merkezi, mağazanın merkezi olarak kabul edilecek ancak böyle bir durumda o tek mağaza şube değil, ticari işletme vasfinda olacaktır. Örneğin sadece Bodrum Limanı'nda mağaza işleten bir anonim şirketin, bu mağazası ticari işletme olarak kabul edilecektir.

Son olarak gümrüksüz satış mağazalarına mal tedarikinin sağlandığı ve onunla deyim yerindeyse bütünlük arz eden ve tıpkı gümrüksüz satış mağazaları gibi özel antrepo niteliğinde bulunan depoların durumunu da değerlendirmek gerekir. Her şeyden evvel depolar, münhasıran ticari faaliyetin yürütüldüğ̈̈ bir yer olarak kabul edilemez. Bu nedenle depoların şube olarak telakki edilememesi gerekir. Ayrıca görüşümüz doğrultusunda gümrüksüz satış mağazasının ticari işletme olarak kabul edilmesi halinde de, depoların ticari işletme ile hukuki ilişkisinin kurulması daha kolay olabilecektir.

77 Kayış, s. 160. Bazı durumlarda kanuni merkezin işlerin yürütüldüğü merkezden ayrılmasının zaruret haline gelebileceği hakkında bkz. İnal, Tamer: Ticari İşletme Hukuku, 2. Bası, Seçkin Yayınları, Ankara, 2015, s. 247. 


\section{Tekel Hakkı}

GSMY'nin 5. maddesinde gümrüksüz satış mağazalarının tekel hakkı düzenlenmiştir. Buradaki tekel hakkının konusunu ilgili yerde mağaza açılması ve mevzuatta öngörülmüş ürünlerin satılması noktasında mağaza işletenin inhisari bir hakka sahip olması teşkil etmektedir. Tekel hakkının muhatabı mağaza açma iznini veren Gümrükler Genel Müdürlüğü ile mağazanın faaliyetlerini yürüttüğü yerde faaliyet gösteren, yer tahsisi yapan ilgili kamu kuruluşu ya da liman, havaalanı, sınır bölgesinin işletme hakkını elinde bulunduran özel hukuk tüzel kişisidir ${ }^{78}$. Böyle bir uygulamanın kabul edilme nedeni ise gümrüksüz satış mağazalarının faaliyetlerinin tek elden denetlenme imkanının sağlanması ve bu yolla olası usulsüzlüklerin en kolay bir şekilde önüne geçilmesinin sağlanmasıdır. Tekel hakkı olarak ifade ettiğimiz bu durum, yönetmeliğin 5. maddesinin başlığında "tek işletmeci" şeklinde düzenlenmiştir ${ }^{79}$. Buna göre her bir hudut kapısının bulunduğu yerde

78 Danıştay 10. D, 17.04.1990 T., E. 1989/2640, K. 1990/898: "Davacı şirketin Cilvegözü Gümrük sahasında Gümrük Hattı Dışı Eşya Satış Mağazası açmak üzere davalı idareye başvurduğu, 25.04.1984 tarihinde açılış izni verilerek gümrük sahasında $100 \mathrm{~m} 2.1$ ik hazineye ait bir arsa tahsis edildiği ve mağazanın inşa edilmesine izin verildiği, tahsis edilen arsanın davacıya 16.10.1984 başlangıç tarihli kira sözleşmesine istinaden kiraya verildiği ve eşya satışına başlandığı, davacı şirketin yasal olarak faaliyetini sürdürdüğü sırada 1986 yılı ortalarına gelindiğinde gümrük sahasının geriye çekileceğinin, bu amaçla $1 \mathrm{~km}$ geride yeni Gümrük tesislerinin yapımına başlandığının öğrenildiği ve 1986 yılı sonlarında gümrük sahasının $1 \mathrm{~km}$ geriye çekildiği, davacıya ait mağazanın da çalışmaz hale gelerek kapatıldığı ve şirketin karavanla satış yapmasına izin verildiği, bu arada davacının kira sözleşmesi de sona ermediği halde yeni sahada inşa edilen 6 adet satış mağazasının 30.06.1988 günü ihaleye çıkarılarak başka firmalara kiralandığı anlaşılmaktadır. Bu durumda davacı şirkete işletmede öncelik hakkı tanınması gerekirken, yeni mağazaların ihale yoluyla başka firmalara kiralanmasına ilişkin işlemde davanın reddi yolundaki idare mahkemesi kararında isabet görülmemiştir.” (www.legalbank.net) (Erişim Tarihi: 08.09.2021)

792006 tarihli Gümrüksüz Satış Mağazaları Yönetmeliği'nin yürürlükte olduğu dönemde tek işletmeci sisteminin dava konusu yapıldığını belirtmek gerekir. Bu davada davacı şirket, "özel sektör ilgili kişileri tarafından mağaza işletmeciliği tek bir işleticiye verilir" hükmünün rekabeti bozarak tekelleşmeye yol açacağı iddiasıyla iptalini talep etmişti. Danıştay "Burada bahsedilen özel sektör ilgili kişileri ise gümrük kapıları ile hava alanlarının işletme hakkını yap-işlet-devret modeli ile devralan özel hukuk tüzel kişileri kastedilmektedir. $\mathrm{Bu}$ kişilerin buraları bizzat işletmeleri ya da işletilmesi amacıyla üçüncü kişilere devretmeleri mümkündür. Bu durumda davalı Gümrük Müsteşarlığı'nın sahip olduğu denetim yetkisini etkili bir şekilde kullanarak hizmetin düzenli olarak işlemesini sağlamak amacıyla gümrüksüz satış mağazalarının tek bir işleticiye verilmesine ilişkin yönetmelik hükümlerinde kamu yararı ve hizmetin gereklerine aykırılık bulunmamaktadır" ifadelerine yer vermek suretiyle yürütülmesinin durdurulması talebinin reddine karar vermiştir. Aynı kararda verilen muhalefet şerhinde ise "gümrüksüz satış 
yalnız bir gümrüksüz satış mağazası kurulabilecektir (GSMY md. 5/1 ve uçakta satış mağazaları için md. 5/3). Bununla birlikte yönetmelik bu kurala çıkışa yönelik mağazalar bakımından bir istisna getirmiş; çıkış tarafında, mağaza açma şartlarını taşıyan ve tek işletmeci ile işletme sözleşmesi bulunan firmalara da alkollü içki, tütün ve tütün mamulleri dışında eşya satışı yapmak üzere mağaza izni verilebileceğini hükme bağlamıştır. Dolayısıyla gümrüksüz satış mağazası işletmecilerinin giden yolcu kısmında alt sözleşmeler yapabilmesine imkân tanınmış bulunmaktadır ${ }^{80}$.

Gümrüksüz satış mağazalarının haiz oldukları bu tekel hakkının ihlal edilmesinin, TTK md. 54 vd. hükümleri uyarınca haksız rekabet davalarına konu teşkil etmesi de mümkündür. Hatta tekel hakkını ihlal edecek fiilin hudut kapısında gerçekleşmesine de gerek bulunmamaktadır ${ }^{81}$.

mağazası işletmeciliğinin tek bir tüzel kişiye verilmesinin rekabet ve eşitlik ilkesinin ihlal edilerek tekelleşmeye yol açacağı, yapılacak ihale sonucunda mevzuatta aranan şartları taşıyan tüzel kişilere mağaza işletme hakkının verilmesi gerektiği” ifade edilmiştir; bkz. Danıştay 10. D, 10.06.2009 T., E. 2009/774, K. YD (www.legalbank.net) (Erişim Tarihi: 08.09.2021)

80 Uygulamada gümrüksüz mağaza işletmelerinin kamu ihale mevzuatı çerçevesinde kiraya verilebildiğini görmekteyiz. Nitekim GSMY de bu duruma kayıtsız kalmamıştır. Yönetmelik md. 5/4 hükmü şu şekildedir: "Kamu kurum ve kuruluşları ile belediyeler, 4 üncü maddenin birinci fikrasında sayılan yerlerde bulunan ve mülkiyetleri veya tasarrufları altında bulundurdukları taşınmazları, Bakanlıktan görüş alınması suretiyle gümrüksüz satış mağazası işletmek üzere tek bir işletmeci tarafından işletilmek şartı ile ilgili ihale mevzuatı çerçevesinde kiraya verebilir. Özel hukuk tüzel kişileri, kamu kurum ve kuruluşları ile belediyeler tarafından kendilerine kiralanan bu yerlerdeki taşınmazları, gümrüksüz satış mağazası işletmek üzere özel hukuk sözleşmeleri çerçevesinde üçüncü kişilere kiralayabilir."

81 Yargıtay 11. HD, 02.06.2014 T., E. 2014/2299, K. 2014/10322: "Davac1 .... olarak adlandırılan gümrük hattı dışı eşya satış mağazası işletmeciliği yaptıklarını, parfüm ve kozmetik ürünlerini satıp pazarlayan davalının 2006 yılından beri ...'lardan Ürün Taş1mayın! Cok Özel Fiyatlar, Özgür Alışveriş Burada!”, “...’in Gözde kozmetik mağazalarından ..., ürün fiyatlarını havaalanları ve sınır kapılarındaki ...la aynı düzeye çekti." şeklinde basın ilanları verdiğini, mağazalarının içinde de aynı ibareleri bulundurduğunu, ancak bu ilanların gerçeği yansıtmadığını, zira davalının ...dan daha pahalıya satış yaptığını, mağazasında bulunan free shop ibaresinin de tüketiciyi yanılttığını, davalının bir free shop mağazası sanılacağını, ilanların gerçeği yansıtmayan karşılaştırmalı reklam vasfinda olduğunu, tüm bu eylemlerin müvekkilleri aleyhine haksız rekabet teşkil ettiğini ileri sürerek haksız rekabetin tespiti ile men'ini, ilanların kaldırılmasını, kararın ilanını talep ve dava etmiştir. Mahkemece, davalının reklamlarında kullandığı ibaresi ile... tüketicide gümrüksüz satış mağazalarındaki gibi ucuz fiyata mal satacağı kanaatini oluşturduğu, ... ibaresini de taşıyan markayı kullanarak yaptığı açıklamalarda tüketicinin bilgi eksikliğinden kaynaklanacak yanlış algılamaya sebep olacağı, davalının aynı fiyata ürün sattığı şeklinde reklam ve tanıtım yapmasının, ürün ve hizmetler için tescil ettirdiği 


\section{Gümrüksüz Satış Mağazalarında Yapılan Satışlar}

Gümrüksüz satış mağazalarının en önemli özelliği, müşteri çevresinin ve satıma konu olabilecek eşyanın sınırlandırılmış olmasıdır. Gerçekten de gümrüksüz satış mağazaları satışlarını kural olarak sadece Türkiye'ye giriş yapan ya da Türkiye'den çıkış yapan yolculara ve transit yolculara gerçekleştirebilecektir ${ }^{82}$. Ayrıca gelen ve giden yolcular için satış sözleşmesine konu olabilecek eşyalar da ayrıca belirlenmiştir (GSMY md. 11). Bu yönüyle gümrüksüz satış mağazalarından elde edilmesi amaçlanan faydanın, yönetmelik tarafından salt diş hatlar yolcusu olma şeklinde belirlenmek suretiyle oldukça sınırlı bir çevreye indirgendiği anlaşıllyor. Bu durumun ise, gümrüksüz satış mağazalarından alışveriş yapamayan kişiler aleyhine önemli ayrımcılık teşkil ettiği açıktır. Böyle bir ayrımcılık ise doğal olarak 1982 Anayasası md. 10 anlamında eşitlik ilkesine aykırılık sonucunu doğuracaktır. Zira kimse yurt dışına çıkmaya zorlanamayacağı gibi, bazı pozitif imkânlardan yararlanmak da yurt dışına çıkma şartına bağlanamaz. Kanımca bu sorunun çözümü için, gümrüksüz satış mağazalarının yurt dışında olduğu gibi internet üzerinden mesafeli satış yapabilmelerine imkân tanımak gerekir. Hâlihazırda ise, bu mağazalar ön sipariş yöntemiyle, sadece mağazaya bizzat gelerek pasaport ibraz edilmesi şartıyla malları teslim etmek suretiyle satış yapabilmektedir.

Yine GSMY md. 11 hükmü bu mağazalarda nelerin satılabileceğini de sınırlı olarak belirtmiştir. Gerçekten de GSMY md. 11/8, mağazalarda kural olarak serbest dolaşıma girmemiş yabancı menşeli eşyanın satılabileceğini belirttikten başka, aynı maddede yer alan ekli listelerde mağazada hangi eşyanın satılabileceği de sınırlı olarak belirtilmiştir. Bir başka ifadeyle mağaza ve depolarda bulunan eşyaların antrepo rejimine tabi olduğu ve kural olarak serbest dolaşıma girmemiş mal statüsünde bulunduğu, bu mağazalarda satışa konu olan eşyaların temel özelliğinin de esasen zaten serbest dolaşıma giriş rejiminden muaf tutulma olduğu görülmektedir. Bununla birlikte mağazalarda Türk menşeli eşya ile serbest dolaşıma girmiş eşyaların da satış1 imkân dâhilindedir (GSMY md. 11/8, ikinci cümle). Ayrıca gümrüksüz satış mağazalarında yapılan satışların, Türkiye'nin gümrük bölgesi içerisinde

free shop ibaresini reklam ve promosyonlarında tasviri nitelikte yanıltıcı ve piyasada karışıklığa yol açacak şekilde kullandığı, yapılan mukayeseli reklamın yasal olmadığı gerekçesiyle davalının haksız rekabette bulunduğunun tespitine, haksız rekabetin önlenmesine, belirtilen ifade ve tanıtımların davalı tarafından kullanımının men'ine, hüküm özetinin ilanına karar verilmiştir.” (www.legalbank.net) (Erişim Tarihi: 08.09.2021)

82 Bunun haricinde nakil vasıtaları sürücü ve hizmetlileri, diplomatik muafiyetten faydalananlara ve yabancı uyruklu basın mensuplarına özgü hükümler de bulunmaktadır. 
gerçekleşmeleri nedeniyle, bundan mütevellit sorunların 6502 sayılı Tüketicinin Korunması Hakkında Kanun'un uygulama alanına gireceğini de kabul etmek gerekir.

Son olarak gümrüksüz satış mağazalarında yapılan satışların fikri mülkiyet hukuku bakımından da irdelenmesi gerekir. GSMY'nin "Fikri ve sinai hakların ihlali" başlıklı 32. maddesinde "Mağazalarda eşya satışının fikri ve sınai haklar mevzuatını ihlal etmesi durumunda ilgili mevzuat hükümlerine göre işlem yapılır" hükmüne yer verilmiştir.

\section{Gümrüksüz Satış Mağazalarının Devri, Rehni ve Haczi}

Gümrüksüz satış mağazalarının devri ile ilgili olarak GSMY md. 18 hükmü özel birtakım düzenlemelere yer vermiştir. Buna göre devreden ve devralan firma bir dilekçe ile ilgili gümrük müdürlüğüne başvuracak, devralan firma dilekçesine ayrıca GSMY md. 7 hükmünde belirtilen ve mağaza açma ve işletme izni için gerekli belgeleri ekleyecektir. Başvurular GSMY md. 7/6 hükmüne göre incelenip, karara bağlanacaktır. Önemle belirtelim ki yönetmelik, gümrüksüz satış mağazası işleten anonim ve limited şirkette pay devri suretiyle pay sahipliğinin değişmesi durumunu düzenlememiştir. Dolayısıyla yönetmelikte pay devri ve pay devri halinde ne şekilde hareket edileceği hususları boş bırakılmıştır. Şu durumda payı devralan ortakların özellikle de GSMY md. 6/3 hükmünde yer alan şartları taşımamaları durumunda nasıl hareket edileceği hususunda bir belirsizlik ortaya çıkmaktadır. Kanımca bu boşluğun mağazanın devri konusundaki md. 18 hükmünün kıyasen uygulanması suretiyle doldurulması mümkündür.

Burada GSMY md. 18/2'de yer alan 'Devralan şirketin yeni kurulmuş bir şirket olması ve kurucu ortaklarından en az birinin asgari beş yıldır faaliyette bulunması hâlinde, şirketin $6 \mathrm{nc}$ maddenin birinci fikrasının (b) bendinde belirtilen beş yıldır faaliyette bulunması şartı aranmaz" şeklindeki düzenlemeden de bahsetmek gerekmektedir. Bu hükmü ile gümrüksüz satış mağazası açmak için md. 6/1-b bendinde aranan "Asgari beş yıldır faaliyette bulunan, ödenmiş sermayeleri ve ihtiyatları toplamı en az 1.000 .000 (bir milyon) TL ve son beş yılda tahakkuk eden kurumlar vergisinin basit ortalaması en az 50.000 (elli bin) TL olan limited veya anonim şirketler" şartı, mağaza devirleri bakımından fiilen bertaraf edilmiş olmaktadır. Kanımca bu düzenleme sektöre yatırım yapmak isteyen ve iktisadi açıdan yeterli kişilerin ve yabancı sermayenin sektörde yer almasını kolaylaştırmak amacıyla kabul edilmiştir. 
Gümrüksüz satıs mağazalarının ticari işletme niteliğine haiz olduklarını yukarıda ifade etmiştim. Bu noktada çeşitli ihtimaller üzerinden yola çıkmak suretiyle bazı meselelerin açıklığa kavuşturulması gerekmektedir. Her şeyden önce gümrüksüz satış mağazasının ticari işletme niteliğinin kabulünün doğal sonucu mağazanın devrinin, ticari işletmenin devri usûlüne tabi olmasıdır. Bu anlamda devir işlemleri TTK md. 11/3 hükümlerine uygun olarak icra edilmelidir. Ancak tek bir gümrüksüz satış mağazasının işletildiği hallerde bu mağazanın devri ya da örneğin üç mağazayı işleten bir anonim şirketin bunlardan biri veya ikisini devretmesi gibi hallerde devrin hukuki dayanağının TTK md. 11/3 hükmünün ötesine geçmesi söz konusu olabilir. Gerçekten de üç mağazanın ikisinin devri gibi durumlar, TTK md. 408/2-f bendi uyarınca önemli miktarda varlığın toptan satışı anlamına geleceğinden bu konuda münhasır yetkisi kapsamında genel kurul kararına ihtiyaç bulunduğu kabul edilmelidir. Zira ticari işletmenin devri de önemli nitelikte malvarlığ kavramına dahildir ${ }^{83}$. Aynı husus tek bir gümrüksüz satış mağazası işleten bir anonim şirketin, bu mağazayı devri halinde de geçerli olacak, burada da genel kurul kararı alınması gerekecektir ${ }^{84}$. Böyle bir durumda faaliyet konusu münhasıran gümrüksüz satış mağazası işletmek olan ticaret

83 Kervankıran, Emrullah: Anonim Şirketlerin Tasfiyesi, 1. Bası, Seçkin Yayınları, Ankara, 2015, s. 236. Tasfiye işleri ile ilgili TTK md. 538/2 bu tip durumlarda genel kurul kararına ihtiyaç bulunduğunu açıkça belirtmiş, aranacak yeter sayı konusunda da TTK md. $421 / 3$ ve 4 hükümlerine atıf yapmış ve karar alınabilmesini için sermayenin en az yüzde yetmiş beşini oluşturan pay sahiplerinin olumlu oyunun varlığ şartına bağlamıştır. Ancak tasfiye halinde olmayan anonim ortaklıklar bakımından hangi yeter sayıların gerekli olduğu konusu ise tartışmalıdır. TTK md. 408/2-f bendi bakımından TTK md. 418 hükmünün uygulanması gerektiği konusunda bkz. Biçer, Levent/ Hamamcıoğlu, Esra: Anonim Ortaklık Genel Kurul Toplantılarında Uygulanan Yetersayılar ve Bazı Değerlendirmeler, Bahçeşehir Üniversitesi Hukuk Fakültesi Dergisi, Cilt: 12, Sayı: 149-150, 2017, s. 82. Diğer görüş ise TTK md. 538/2 hükmünün TTK md. 408/2-f bendinde ifadesini bulan genel kurul kararının alınmasına kıyasen uygulanması gerektiği şeklindedir; bkz. Ayoğlu, Tolga: Önemli Miktarda Şirket Varlığının Satışında Genel Kurul Kararının Hukuki Niteliği, Kadir Has Üniversitesi Hukuk Fakültesi Dergisi, Cilt: 5, Sayı: 1, 2017, s. 95. Anonim Şirketlerin Genel Kurul Toplantılarının Usul ve Esasları ile Bu Toplantılarda Bulunacak Bakanlık Temsilcileri Hakkında Yönetmelik md. 22/12 söz konusu kararın sermayenin en az yüzde yetmişbeşini oluşturan pay sahiplerinin oyu ile alınacağına ilişkin bir hüküm sevk etmiş olsa da böyle bir düzenlemenin yönetmelik ile yapılamayacağı açıktır; bkz. aynı yönde Bahtiyar, Mehmet: Ortaklıklar Hukuku, 13. Bas1, Beta Yayınları, İstanbul, 2019, s. 181, dn. 261; Bilgili, Fatih/Demirkapı, Ertan: Şirketler Hukuku, 1. Bası, Dora Yayınları, Bursa, 2013, s. 262, dn. 298.

84 Karaman Coşgun, Özlem: Anonim Şirketin Tasfiyesi, 1. Bası, Adalet Yayınevi, Ankara, 2015, s. 202. 
şirketlerinde, tek mağazanın devri halinde şirketin sona ermesi dahi söz konusu olabilecektir (TTK md. 529/1-b) ${ }^{85}$. Son olarak tek bir mağazanın işletildiği hallerde, mağazanın işleteni olan ticaret şirketinin, diğer şirketle şirket birleşmesi yoluna giderek mağazayı devretmesinin de imkân dâhilinde olduğu belirtilmelidir (TTK md. 136). Nihayet limited şirketlerde de şirketin önemli miktarda varlığının satışı ile ilgili kararların genel kurul tarafından alınması gerektiği kabul edilmektedir ${ }^{86}$.

Devir konusunda karşımıza çıkabilecek diğer ihtimal, birden fazla mağaza işletilmesi durumunda şube niteliğinde olan mağazaların devrinin mümkün olup olamayacağ 1 hususudur. Genel olarak şubenin, işletmeden bağımsız şekilde münhasıran devri konusu doktrinde ihtilaflıdır. Kendigelen TTK md. 11/3 hükmünün ticari işletmenin külli olarak devri ile ilgili bir husus olduğu, şubenin devri gibi durumlara uygulanamayacağı, bu tip hallerde genel hükümlere göre hareket edilmesi gerektiği kanaatindedir ${ }^{87}$. Yazar özellikle de ticaret şirketlerine ait şubelerin devrinden evvel, şubenin ayrı bir ticaret şirketi kurulmak suretiyle bu şirketin malvarlığına dâhil edilmesinin uygun bir çözüm olacağı kanısındadır. Kayış ise şubenin, TTK md. 11/3 kapsamında devrinin mümkün olduğunu düşünmektedir ${ }^{88}$. Yazar, bağım-

85 Ancak Kervankıran klasik doktrinde kabul edilen bu yaklaşımın gerçekleşme ihtimalinin çok zayıf olduğu kanısındadır. Yazara göre söz gelimi tek iştigal sahası inşaat işleri olan bir anonim şirketin, mevcut inşaatın tamamlanması ile sona ermesi oldukça mantıksızdır. Zira bu şirket yeni bir inşaat işi alabilir. Aynı zamanda bir şirketin işletme konusunda değişikliğe gitmesi de her zaman için mümkündür. Yazar bu düşüncelerinde haklıdır. Gümrüksüz satış mağazaları açısından konuyu ele aldığımızda tek bir gümrüksüz satış mağazası işleten bir anonim şirketin, bu mağazayı devretmesinden sonra başka bir mağaza devralması ya da işletme konusunu değiştirmesi mümkündür. Ancak yazarın belirttiği bu hususların birer imkân olduğu unutulmamalıdır. Böyle bir durum söz konusu olmadığ 1 takdirde ise klasik doktrin devreye girebilecektir; bkz. Kervankıran, s. 31.

86 Çebi, Hakan: Limited Şirketler Hukuku, 1. Bası, Adalet Yayınevi, Ankara, 2019, s. 101, dn. 189. Buna karşılık Çamoğlu tasfiye halinde olmayan limited şirketlerde önemli miktarda malvarlığı satışına dair yetkinin müdürde olduğu kanaatindedir; bkz. Çamoğlu, Ersin: Limited Ortaklıklar Hukukunun Temel İlkeleri, 1. Bas1, Vedat Kitapçıllı, İstanbul, 2020, s. 129. Yargitay 11. HD, 28.01.2021 T., E. 2019/2449, K. 2021/552: "Kural olarak şirketi temsile yetkili müdürün şirkete ait bir malvarlığı üzerinde tasarrufta bulunabileceğinin kabulü gerekir. Ancak bu malvarlığının, şirketin sahip olduğu tek malvarlığı olduğunun ve şirketin varlığını sürdürebilmesi için hayati önemi haiz bulunduğunun belirlenmesi halinde bu kez, olaya uygulanacak 6102 sayılı TTK'nın 538. maddesi uyarınca şirketin fiilen tasfiyesine yol açacak ölçüde aktiflerinin toptan satılması şirket genel kurulunun yetkisindedir." (https://karararama.yargitay.gov.tr/Yargitay BilgiBankasiIstemciWeb/ ) (Erişim Tarihi: 08.09.2021)

87 Kendigelen (Ülgen/Helvac1/Kaya/Nomer Ertan), s. 198-199.

88 Kayış, s. 283. 
sızlık kıstasının TTK md. 11/3 hükmünün şube devirlerine uygulanabilirliği açısından bir engel teşkil etmediğini zira önemli olan hususun şubenin devrine yönelik iradenin, şubeyi ticari işletmeye dönüştürmeyi ve dolayısıyla bağımlılı̆̆ı sona erdirmeyi amaçlayan bir irade olacağını savunmaktadır. Gümrüksüz satış mağazaları bakımından Kendigelen'in görüşleri amaca daha uygun olmakla birlikte birtakım sıkıntıları da beraberinde getirebilecektir. Gerçekten de bu mağazaların devri GSMY'nin özel bazı hükümlerinin dikkate alınmasını gerekli kılmaktadır. Bu durumda şubenin evvela gerekli şartları haiz bir tüzel kişi ticaret şirketi bünyesine almasını müteakip, TTK'nın birleşme hükümlerine gidilecektir. Ancak böyle bir yöntemin benimsenmesi sürecin oldukça uzamasına sebebiyet verebileceği gibi, birleşme nedeniyle şirket alacaklılarının ve pay sahiplerinin haklarının korunması meselesi gündeme gelecek, böylelikle de devir çok daha zorlaşabilecektir. Ayrıca şirket birleşmesinden ziyade bölünme yoluyla da aynı amaca ulaşılması mümkündür. Sonuç olarak mevcut bir şirketin, gümrüksüz satış mağazasını devralmak istemesi durumunda, birleşme usulüne başvurmadan, TTK md. 11/3 uyarınca mağazanın devrinin gerçekleştirilmesi en pratik çözüm olarak karşımıza çıkmaktadır. Nitekim GSMY md. 18 hükmü de "mağazanın devri” ifadesini kullanmıştır.

Gümrüksüz satış mağazalarının rehin işlemlerine konu olması da mümkündür. Bu durumda 6750 sayılı Ticari İşlemlerde Taşınır Rehni Kanunu (TITTRK) hükümleri uygulama alanı bulabilecektir. Ancak burada borcun ifa edilmemesi halinde 6750 sayılı TITRK md. 14 hükmünde ifadesini bulan temerrüt sonrası hakların kullanılmasının nasıl gerçekleşeceği sorusu akla gelecektir. Özellikle de md. 14/1'in a bendinde yer alan, birinci derece alacaklının icra dairesinden İ̈K uyarınca rehinli taşınırın mülkiyetinin devrinin talep edilebileceğine ilişkin hüküm birtakım uygulama sorunlarına sebebiyet verebilecektir. Zira alacaklı, GSMY anlamında mağaza açma ve işletme şartlarını taşımayabilir. Bu durumda TITRK md. 14/1-c bendinde yer alan "zilyetliğin devrine konu olmayan varlıklarda kiralama ve lisans hakkını kullanabilir" hükmünden yola çıkarak hareket edilmesi mümkündür ${ }^{89}$. Kiralama ve lisans hakkı geniş olarak anlaşılmakta belli bir sicile kaydı öngö-

89 Nitekim 31.12.2016 tarihli ve 29935 sayılı Resmî Gazete'nin 3.mükerrer sayısında yayınlanarak yürürlüğe giren Ticari İşlemlerde Rehin Hakkının Kurulması ve Temerrüt Sonrası Hakların Kullanılması Hakkında Yönetmelik md. 41/2, "Kanunun 5 inci maddesinde sayılan varlıklardan mülkiyeti veya zilyetliği devredilemeyenlerin kiralama ve lisans hakkını doğrudan kullanabilir veya üçüncü kişilere kullandırtabilir. Lisanslama ve kiralama geliri borca yetecek düzeye ulaştıktan sonra kiralama ve lisanslama hakkı sona erer" ifadelerini kullanmaktadır. 
rülmeyen idari izin ve ruhsatları da kapsadığ kabul edilmektedir ${ }^{90}$. Alacaklı kiralama ve lisans hakkını bizzat kullanabileceği gibi, üçüncü kişiler eliyle de bunu gerçekleştirebilecek ve her halükârda kiralama ya da lisans hakkının kullanılmasından elde edilen gelirin alacaklının alacağını karşılamasından sonra hakkın kullanımı da sona erecektir ${ }^{91}$. Burada gümrük idareleri tarafından alacaklıya, işletmeyi elden çıkartması için makul bir süre verilmesi de çözüm yolu olarak düşünülebilir. Ancak kanımca en mantıklı çözüm TITRK md. 14/1-ç bendinde yer alan genel hükümlere göre takip yapmak olarak karşımıza çıkmaktadır. Genel hükümlere göre yapılan takiplerde ise satış ilanında mağazanın işletilmesi bakımından gerekli olan şartların belirtilmesi önem taşımaktadır ${ }^{92}$.

Bir diğer hususiyet arz eden durum da malların haciz ve satış işlemlerinde kendini göstermektedir. Uygulamada Gümrükler Genel Müdürlüğü'nün 2000/42 sayılı ve Gümrük ve Ticaret Bakanlığı hukuk müşavirliğinin 2012/1 sayılı genelgeleri, icra müdürlüklerinin üçüncü kişilerin hacizli alacakları bakımından gümrük idarelerine yapılacak bildirimlere ilişkin birtakım uygulama kuralları getirmiştir. Söz konusu genelgelerde, getirilen kuralların hukuki dayanağının Gümrük Kanunu md. 10 hükmü olduğu belirtilmiştir. Buna göre icra müdürlüklerinin aldıkları haciz ve diğer kararların bildiriminin geçici depolama yeri ve antrepo işleticisine yapılması ve bunların da kayıtlarına haciz şerhini düşmelerinin akabinde durumu ilgili gümrük idaresine bildirmeleri öngörülmüş̧; eşyanın gümrük sahasında bulunması ya da geçici depolama yeri ile antreponun gümrük idaresince işletilmesi halinde ise, bildirimlerin malların bulunduğu yerdeki gümrük idarelerine yapılması gerektiği ifade edilmiştir ${ }^{93}$. Ancak genelgelerde bizzat antrepo işleticisine ait malların nasıl haczedileceğine ilişkin bir düzenlemeye yer verilmemiştir. Keza Lisanslı Yediemin Depoları Yönetmeliği ${ }^{94}$ md. 18/5 hükmü antrepodaki malın haczi halinde yediemin olarak antrepoda birakılmasına

90 Yurtman, Hazalcan: 6750 Sayılı Ticari İşlemlerde Taşınır Rehni Kanunu Uyarınca Temerrüt Sonrası Haklar, 1. Bası, On İki Levha Yayıncılık, İstanbul, 2021, s. 169-170.

91 Şenocak, Kemal/Kahraman, Zafer/Tuncer Kazancı, İdil/Öcal Apaydın, Bahar: Ticari İşlemlerde Taşınır Rehni, 1. Bası, Yetkin Yayınları, Ankara, 2019, s. 189.

92 Öğretide ticari plaka örneği üzerinden yola çıkılarak ticari plakanın ancak belirli şartları taşıyanlara satılabileceği bu nedenle bu konuda gerekli açıklamaya yer verilmesi gerektiğinin altı çizilmiştir. Keza rehinli alacaklının şartları taşımaması durumunda ticari plakanın gelirinin kendisine tahsis edilebileceği kabul edilmektedir; bkz. Şenocak/ Kahraman/Tuncer Kazancı/Öcal Apaydın, s. 205.

93 Savaş, Deniz Okan: Serbest Dolaşıma Girmemiş Eşyanın Haczi ve Haciz Sonrası Vergisel Sorumluluk, Gümrük ve Ticaret Dergisi, 2013/1, s. 76.

$94 \quad$ 23.08.2016 Tarihli ve 29810 say1l RG 
imkân tanımış olsa da, burada da bizzat antrepo işleticisine ait malların akıbeti ile ilgili hüküm sevk edilmemiştir. GSMY md. 22 hükmü uyarınca, mağazaların antrepo giriş-çıkış defteri tutmakla yükümlü olması, mağazalardaki tüm malların elektronik ortamda kaydının tutulması ve BİLGE olarak adlandırılan gümrük sistemi yazılımından takip edilebilmesi nedeniyle, esasen mağazadaki malların haciz işleminin İIK md. 78 uyarınca elektronik ortamda doğrudan icra dairesi tarafından gerçekleştirilmesi de mümkündür. Bununla birlikte gümrüksüz satış mağazalarında yer alan malların serbest dolaşıma girmemiş mal statüsünde bulunması ve pek çok aşamada gümrük idarelerinin denetimine tabi olmas1, kayıtların gümrük idarelerinde mevcut olması nedeniyle, gümrükler nezdindeki icra ve iflas işlemleri konusunda bildirimlerin ilgili gümrük idaresine de yapılmasının işlem güvenliği ve alacaklıların korunması açısından gerekli olduğu kanaatindeyim.

Ayrıca gümrüksüz satış mağaza ve depolarında bulunan mahcuz malların satışı ise özel önem arz etmektedir. Zira söz konusu mallar henüz serbest dolaşıma girmemiş mal olması nedeniyle malların satışa konu olabilmesi için serbest dolaşıma giriş rejimine tabi tutulması gerekebilecektir. $\mathrm{Bu}$ durumda satış işlemlerine başlanmadan evvel ithal izni alınması bir zaruret olarak karşımıza çıksa da, uygulamada daha ziyade malların satışından sonra, bizzat ihaleyi kazanarak malları satın alan kişi tarafından ithal izni için başvuruda bulunulduğu görülmektedir ${ }^{95}$.

\section{SONUÇ}

Gümrüksüz satış mağazalarının bünyesinde barındırdığı avantajları tabana yayabilmesi onlara tüm dünyada teveccüh gösterilmesine neden olmuştur. Gerçekten de bu mağazalar hem sahibine hem bulunduğu ülkeye ve hem de bu mağazalardan alışveriş yapanlara yüksek katma değer sunma potansiyelleri nedeniyle giderek yaygınlaşmaktadır. Nitekim gümrüksüz satış mağazalarına ilişkin hukuki düzenlemeleri ele aldığımız bu çalışmanın ilk aşamasında gerçekleştirdiğimiz karşılaştırmalı hukuk araştırmasında, dünyada pek çok ülkenin pozitif hukuklarında bu mağazalarla ilgili hükümlere yer verdiğini tespit ettik. Yaptığımız karşılaştırmalı hukuk araştırması neticesinde hemen tüm ülkelerde gümrüksüz satış mağazalarının antrepo olarak kabul edildikleri görülmüştür. Yine karşılaştırmalı hukuk araştırması neticesinde tespit ettiğimiz bir diğer husus da gerçek kişilerin, gümrüksüz satış mağazası işletebilmesi hususunda her ülkenin farklı bir sistem benimsemiş olduğudur. Hemen tüm ülkelerde ortak olan noktalar ise, mağaza işle-

95 Savaş, s. 78 vd. 
tenler hakkında ayrıntılı iktisadi ve hukuki istihbarat araştırması yapılması ve mağaza açmak için gerekli şartların kaybı halinde mağaza açma izninin iptal edilmesidir. Mağazanın devrinin sonuçları bakımından ise farklı sistemler söz konusudur.

Ülkemizde de gümrüksüz satış mağazalarına ilişkin düzenlemelerin çok eskilere kadar gittiği ve 1999 yılına kadar bu mağazaların genel antrepo, bu tarihten sonra ise özel antrepo olarak kabul edildiği görülmektedir. Ayrıca mağaza ile mağazanın stok ihtiyaçlarının sağlanması amacıyla açılan depolar bir bütün teşkil etmektedir. Bunun yanı sıra gümrüksüz satış mağazalarının, her ne kadar satış mağazası olarak adlandırılsalar da, TTK anlamında ticari işletme niteliğine sahip olduğu görülmektedir. Ancak birden fazla mağazanın işletildiği durumlarda diğer mağazaların ayrı bir ticari işletme olarak ya da merkez ve şube ilişkisi ihdas edilmesi suretiyle işletilmesi mümkündür. Her halükârda bir mağazanın ticari işletme olarak kabul edilmesi ise şarttır. Türk hukukunda GSMY sadece kamu kuruluşları ile anonim ve limited şirketlerin gümrüksüz satış mağazası işletebileceğini hükme bağlamıştır. Kanımca gerçek kişilere de gümrüksüz satış mağazası işletebilme imkanının tanınması gerekmektedir.

Gümrüksüz satış mağazasının ticari işletme niteliği gereği, mağazanın devri de, TTK md. 11/3 hükümlerine göre gerçekleşecektir. Ancak şirketin, tek bir mağaza işletmesi durumunda şirket birleşmesi yoluyla da mağazayı devretmesi mümkündür. Eğer ortada birden fazla mağaza varsa, şube niteliğindeki mağazaların devrinin mümkün olduğu ancak bunun için öncelikle söz konusu şubenin GSMY hükümlerine uygun bir ticaret şirketi bünyesine alınması ve daha sonra TTK'nın birleşmeye ilişkin hükümlerine göre devrin gerçekleştirilmesi ortaya çıkması muhtemel sorunların daha baştan önüne geçilmesini sağlayabilecektir. Belirtelim ki, bu yöntem çeşitli sakıncaları da beraberinde getireceğinden, TTK 11/3 uyarınca gerçekleştirilecek bir devir işlemi daha pratik bir yol olarak karşımıza çıkacaktır. Ayrıca özellikle de tek bir gümrüksüz satış mağazası işletildiği hallerde, mağazanın devri için anonim ve limited şirketlerde genel kuruldan karar alınması gerekmektedir.

Gümrüksüz satış mağazaları üzerinde, TİTRK hükümlerine göre rehin işlemleri tesis edilebilse de, söz konusu kanunun 14. maddesinde ifadesini bulan temerrütten doğan hakların, bu mağazaların mahiyeti gereği nasıl uygulanacağı belirsizdir. Bu konuda en mantıklı çözümün genel hükümlere göre takip yapılması olduğu kanaatindeyim (TİTRK md. 14/1-ç). 


\section{KAYNAKÇA}

Aksu, Mustafa: Gümrüksüz Satış Mağazalarında Pazarlama Organizasyonu, (Yayımlanmamış Doktora Tezi), İstanbul, 1989.

Arkan, Sabih: Ticari İşletme Hukuku, 24. Bası, Banka ve Ticaret Hukuku Araştırma Enstitüsü Yayınları, Ankara, 2018.

Ayhan, Rıza/Çağlar, Hayrettin/Özdamar, Mehmet: Ticari İşletme Hukuku Genel Esaslar, 12. Bası, Yetkin Yayınları, Ankara, 2019.

Ayoğlu, Tolga: Önemli Miktarda Şirket Varlığının Satışında Genel Kurul Kararının Hukuki Niteliği, Kadir Has Üniversitesi Hukuk Fakültesi Dergisi, Cilt: 5, Say1: 1, 2017, s. 93-104.

Bahtiyar, Mehmet: Ortaklıklar Hukuku, 13. Bası, Beta Yayınları, İstanbul, 2019.

Biçer, Levent/Hamamcioğlu, Esra: Anonim Ortaklık Genel Kurul Toplantılarında Uygulanan Yetersayılar ve Bazı Değerlendirmeler, Bahçeşehir Üniversitesi Hukuk Fakültesi Dergisi, Cilt: 12, Sayı: 149150, 2017, s. 71-134.

Bilgili, Fatih/Demirkapı, Ertan: Şirketler Hukuku, 1. Bası, Dora Yayınları, Bursa, 2013.

Canıtez, Murat: Uygulamalı Gümrük Mevzuatı, 1. Bası, Gazi Kitabevi Yayınları, Ankara, 2017.

Çamoğlu, Ersin: Limited Ortaklıklar Hukukunun Temel İlkeleri, 1. Bası, Vedat Kitapçılık, İstanbul, 2020.

Çebi, Hakan: Limited Şirketler Hukuku, 1. Bası, Adalet Yayınevi, Ankara, 2019.

Dölek, Ali: Gümrük İşlemleri,1. Bası, Umut Kitap Basım Yayım Dağıtım, İstanbul, 2013.

Ercan, Tayfun: Gümrük Hukuku, 1. Bas1, Ekin Yayınları, Bursa, 2019.

Göle, Celal: Ticari İşletmenin Merkez ve Şubesinin Tayini Sorunu, Prof. Dr. Ernst E. Hirsch'in Hatırasına Armağan, Ankara, 1986, s. 181-206.

Hirş, E.: Ticaret Hukuku Dersleri, 3. Bası, İsmail Akgün Matbaası Hak Kitabevi, İstanbul, 1948.

İnal, Tamer: Ticari İşletme Hukuku, 2. Bası, Seçkin Yayınları, Ankara, 2015. 
Kaliç, Özkan: Gümrüksüz Satış Mağaza Faaliyetlerinin Bilgisayar Desteğinde Yürütülmesi ve Bir Uygulama Örneği, (Yayımlanmamış YL Tezi), İstanbul, 1992.

Karaman Coşgun, Özlem: Anonim Şirketin Tasfiyesi, 1. Bası, Adalet Yayınevi, Ankara 2015.

Karayalçın, Yaşar: Ticaret Hukuku Dersleri I.Giriş-Ticari İşletme, 2. Bası, Banka ve Ticaret Hukuku Araştırma Enstitüsü Yayınları, Ankara, 1960.

Kayış, Ferhat: Ticari İşletmede Şube Kavramı ve Şube Olmaya Bağlanan Hukuki Sonuçlar, 1. Bası, On İki Levha Yayıncılık, İstanbul, 2019.

Kendigelen, Abuzer (Ülgen, Hüseyin/Helvac1, Mehmet/Kaya, Arslan/ Nomer Ertan, Füsun): Ticari İşletme Hukuku, 4. Bası, On İki Levha Yayınc1lı, İstanbul, 2015.

Kervankıran, Emrullah: Anonim Şirketlerin Tasfiyesi, 1. Bası, Seçkin Yayınları, Ankara 2015

Özdamar, Mehmet: Yargıtay Kararları Işı̆̆ında Ticari İşletmede Şube Kavram1, Ankara Barosu Dergisi, 2007/1, s. 48-61.

Pekdinçer, Tamer: Ticaret Sicili Açısından Merkez-Şube-Satış Mağazası Kavramları, Prof. Dr. Fahiman Tekil'in Anısına Armağan, s. 471-479.

Savaş, Deniz Okan: Serbest Dolaşıma Girmemiş Eşyanın Haczi ve Haciz Sonrası Vergisel Sorumluluk, Gümrük ve Ticaret Dergisi, 2013/1, s. 74-83.

Seely, Antony: Duty-free shopping, House of Commons Library Research Paper 99/74, 1999. Duty-free shopping (parliament.uk)

Sektör Tanıtımı, Gümrüksüz ve Vergisiz Satış Mağazaları (Duty-Free) İşletmeciliği, Gümrük ve Ticaret Dergisi, 2013/1, s. 118-119.

Selen, Ufuk: Gümrük İşlemleri ve Vergilendirilmesi, 9. Bası, Ekin Yayınları, Bursa, 2017.

Şener, Oruç Hami: Ticari İşletme Hukuku, 2. Bası, Seçkin Yayınları, Ankara, 2020.

Şener, Oruç Hami: Ticari Temsilci ve Ticari Temsil Yetkisi, 1. Bası, Adalet Yayınevi, Ankara, 2015.

Şenocak, Kemal/Kahraman, Zafer/Tuncer Kazancı, İdil/Öcal Apaydın, Bahar: Ticari İşlemlerde Taşınır Rehni, 1. Bası, Yetkin Yayınları, Ankara, 2019.

Tekin, Abdulkadir/Tekin, Ümit Engin: 4458 Sayılı Gümrük Kanunu'na Göre Gümrük İşlemleri, 2. Bası, Seçkin Yayınları, Ankara, 2018. 
Türk Hukuk Lügati, Türk Hukuk Kurumu, 3. Bas1, Türk Hukuk KurumuBaşbakanlık Mevzuatı Geliştirme ve Yayın Genel Müdürlügü, Başbakanlık Basımevi, Ankara, 1991.

Ülgen, Hüseyin/Helvacı, Mehmet/Kaya, Arslan/Nomer Ertan, Füsun: Ticari İşletme Hukuku, 6. Bası, Vedat Kitapçılık, İstanbul, 2019.

Yerci, Cahit: Gümrük Hukuku ve Davaları, 2. Bası, Seçkin Yayınları, Ankara, 2020.

Yeşilova, Alper: Gümrük Hukukuna İlişkin Uyuşmazlıklar ve Hukuki Çözüm Yolları, 1. Bası, Seçkin Yayınları, Ankara, 2017.

Yılmaz, Ejder, Hukuk Sözlüğü, 5. Bası, Yetkin Yayınları, Ankara, 1996.

Yurtman, Hazalcan: 6750 Sayılı Ticari İşlemlerde Taşınır Rehni Kanunu Uyarınca Temerrüt Sonrası Haklar, 1. Bası, On İki Levha Yayıncılık, İstanbul, 2021.

\section{INTERNET KAYNAKLARI}

Botschaft zum Bundesgesetz über den Einkauf von Waren in Zollfreiläden auf Flughäfen, 12. März 2010, https://www.admin.ch/opc/de/federalgazette/2010/2169.pdf

Brendan O'Regan | The Times

Customs Act 1901 (legislation.gov.au)

Customs-Free Airport Act, 1947 (irishstatutebook.ie)

Customs-Free Airport (Amendment) Act, 1958 (irishstatutebook.ie)

Customs Regulation 2015 (legislation.gov.au)

Duty Free Is Cheaper: Myth, Or Fact? (godsavethepoints.com)

Duty-Free Operators' Guide, Australian Goverment Department of Immigration and Border Protection, July 2017, Duty Free Shop Operators' Guide July 2017 (abf.gov.au)

EC Case No COMP/M.5123 Autogrill/ World Duty Free, Notification of 7 April 2008 pursuant to Article 4 of Council Regulation No 139/2004. m5123_20080516_20310_en.pdf (europa.eu)

eCFR :: Title 19 (federalregister.gov)

ETRC - Arrivals Duty Free

Excise Notice 196: excise goods - registration and approval of warehousekeepers, warehouse premises, owners of goods and registered consignors - GOV.UK (www.gov.uk) 
Excise Notice 197a: excise goods - holding and movement - GOV.UK (www.gov.uk)

Global Travel Retail Change 2018 v 2017, PowerPoint Presentation (dfworldcouncil.com)

http://dfworldcouncil.com/what-is-duty-free-travel-retail/

http://search.chinalaw.gov.cn/law/detail?LawID $=405204$

https://ec.europa.eu/commission/presscorner/detail/en/MEMO_97_82

https://karararama.yargitay.gov.tr/YargitayBilgiBankasiIstemciWeb/

https://laws-lois.justice.gc.ca/eng/regulations/sor-86-1072/FullText.html

https://law.moj.gov.tw/ENG/LawClass/LawAll.aspx?pcode=G0350036

https://www.admin.ch/opc/de/classified-

compilation/20030370/index.html\#a17

https://www.admin.ch/opc/de/classified-compilation/20052713/index.html

https://www.cbsa-asfc.gc.ca/publications/dm-md/d4/d4-3-2-eng.html

https://www.toll.no/contentassets/eb096d765fd3460c9415b6a3d158aec1/ove

rsettelse-av-tollforskriften-siste-endringer-per-1.-mai-2020.pdf

Legalbank - ELEKTRONIK HUKUK BANKASI - Mahkeme Kararları, Mevzuat, Dilekçe ve Belgeler, Açıklamalar, Makaleler

Receive goods into and remove goods from an excise warehouse (Excise Notice 197) - GOV.UK (www.gov.uk)

UCC - Legislation | Taxation and Customs Union (europa.eu)

Zoll online - Reisefreimengen 